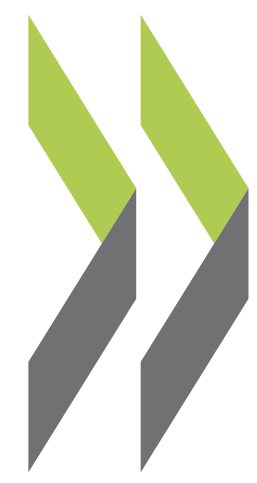

OECD Economics Department Working Papers No. 409

Public Expenditure Management in France
Andrew Burns,

\section{Alessandro Goglio}


Organisation de Coopération et de Développement Economiques

ECONOMICS DEPARTMENT

PUBLIC EXPENDITURE MANAGEMENT IN FRANCE

ECONOMIC DEPARTMENT WORKING PAPERS No. 409

By Andrew Burns and Alessandro Goglio

All Economic Department Working Papers are now available through OECD's Internet Web at http://www.oecd.org/eco 


\section{ABSTRACT \\ PUBLIC EXPENDITURE MANAGEMENT IN FRANCE}

Since the early 1990s, when France's general government deficit reached a disturbing 6 per cent of GDP, the country's public finances have progressed substantially, even though significantly further improvement is required. This paper examines the tools available to policy-makers to meet this challenge. The clearest message is that, given the relatively small size of the State Budget in total spending, the challenge cannot be met by the State sector alone. Social security, as the principal source of spending pressure, must play a role, but so too must sub-national government -- especially if current plans to transfer additional responsibilities to the local level go through. If policy-makers are to succeed in directing public expenditure so as to create this room, they will have to clarify governance structures so that those who administer programmes face appropriate incentives to control costs and maximise programme efficiency.

JEL classification: H0, H1, H4, H5, H6, H7

Keywords: Public expenditure, general government, budgetary transparency, multi-year budgeting, program evaluation

Also available in French under the title:

"La gestion des dépenses publiques en France"

Application for permission to reproduce or translate all, or part of, this material should be made to: Head of Publication Service, OECD, 2, rue André Pascal, 75775 Paris Cedex 16, France. 


\section{TABLE OF CONTENTS}

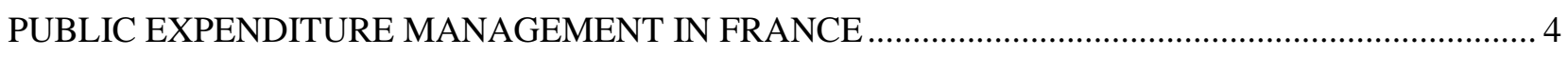

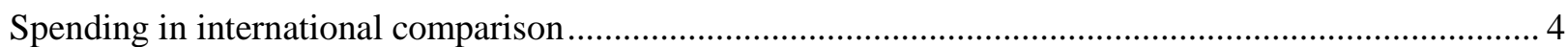

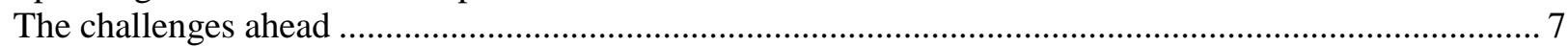

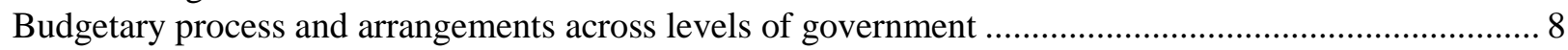

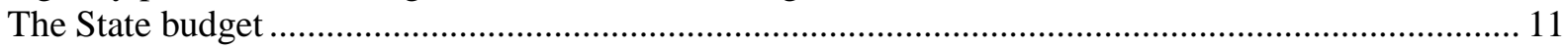

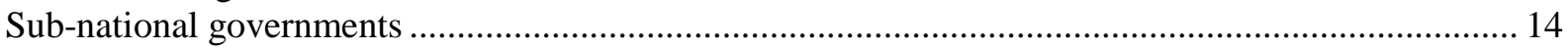

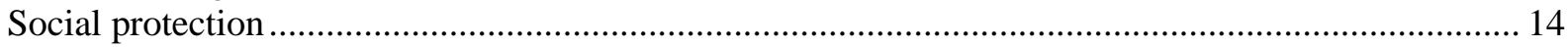

Policies to strengthen public expenditure management …................................................................. 17

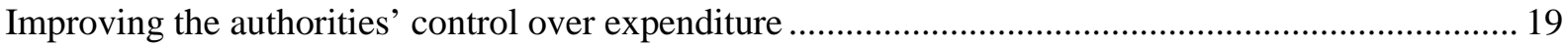

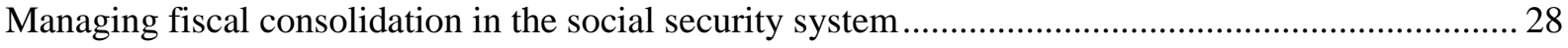

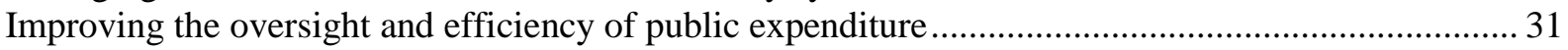

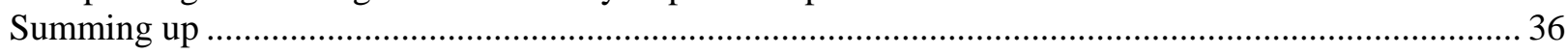

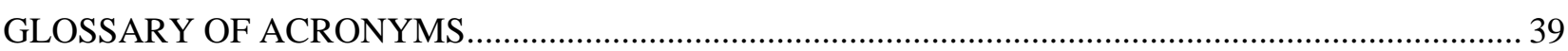

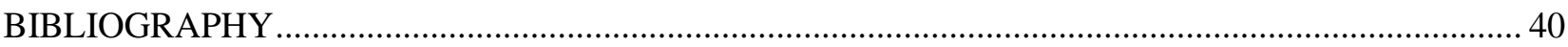

\section{Tables}

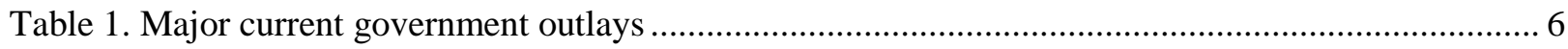

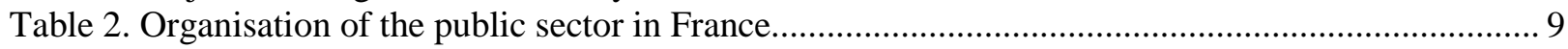

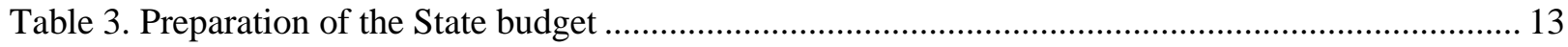

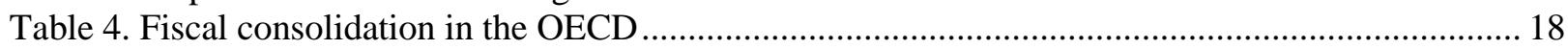

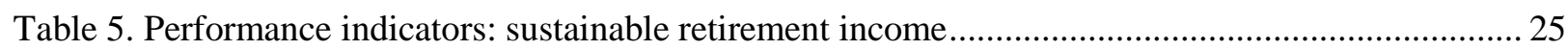

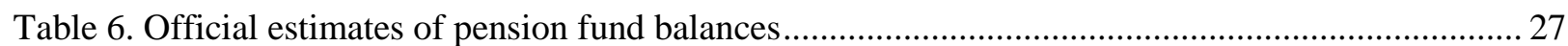

\section{Figures}

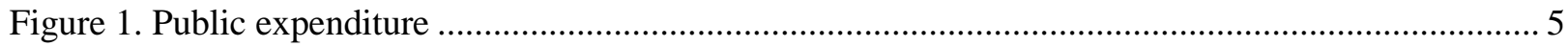

Figure 2. General government primary expenditure by economic category ……..................................... 7

Figure 3. Expenditure shares by level of government .......................................................................... 11

Figure 4. Slippage in multiyear targets ........................................................................................... 19

Figure 5. Asymmetric response of expenditures to the economic cycle ……........................................ 22

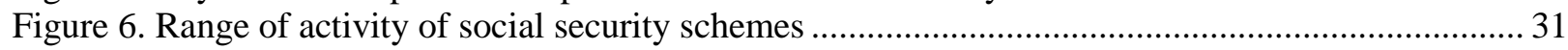

\section{Boxes}

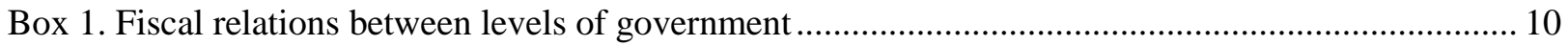

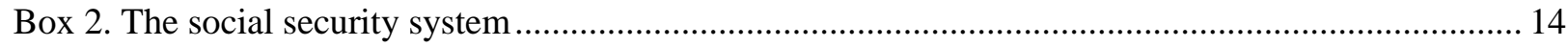

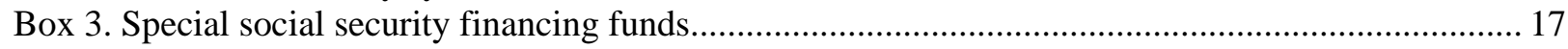

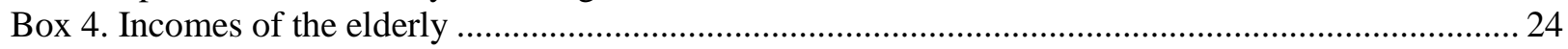

Box 5. Main difference between public- and private-sector pension schemes ...................................... 26

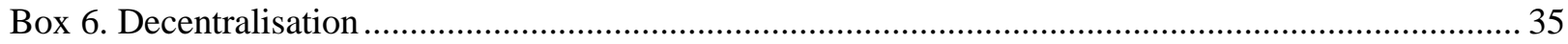

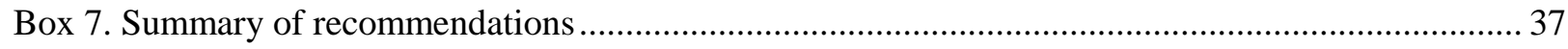




\section{PUBLIC EXPENDITURE MANAGEMENT IN FRANCE Andrew Burns and Alessandro Goglio ${ }^{1}$}

1. The past 50 years have seen the role of the public sector change dramatically in France. As the economy grew and society became richer, the public sphere took on increasing responsibility for providing services to the population. For the most part, responsibility for administering the delivery of these services has been delegated to the social partners and sub-national levels of government. As a consequence, the share of the State Budget in total spending has decreased in line with the increase in government expenditure. These developments reached a point in the 1990s where the taxes required to pay for all of these programmes was increasingly recognised as having reached unacceptably high levels. This, plus the growing awareness that the ageing of the population would put substantial additional demands on the public purse (while at the same time slowing the pace of economic growth), appears to have brought the course of public expenditure in France to a turning point. For several years now the authorities have sought to control the expansion in government spending, with limited success. This paper examines the tools available to the authorities to manage public expenditure, with a view to recommending reforms that will simultaneously help preserve fiscal sustainability and allow society to enjoy the high level of public services to which it has been accustomed.

2. The remainder of this paper is organised as follows. A first section situates public expenditure both internationally and over time. It is followed by a short description of factors likely to influence public spending over the next several decades. A brief description of the institutions of public expenditure in France and the budget process is then followed by a longer section outlining areas where policy reform might improve the capacity of existing institutions to respond to tomorrow's challenges. A final section summarises the recommendations of this paper.

\section{Spending in international comparison}

3. At the beginning of the 1970s total general government expenditures in France were equal to 40 per cent of GDP (Figure 1, Panel A), 8 percentage points higher than the OECD average at that time but close to the average of current-day EU countries. During the following decades they increased rapidly, peaking at about 55 per cent by the mid 1990s. ${ }^{2}$ Most recently, the share of public expenditure in output has stabilised (on a cyclically adjusted basis), although at 54 per cent of GDP, it is still the third highest in the OECD, 16 percentage points higher than the OECD average and 8 percentage points above the

1. This paper was originally produced for the 2003 OECD Economic Survey of France, which was published in July 2003 under the authority of the Economic and Development Review Committee. At the time of writing, Andrew Burns was senior economist on the France/Poland Desk in the Economics Department, where Alessandro Goglio was working as an economist. The authors would like to acknowledge Jean-Philippe Cotis, Val Koromzay, Andrew Dean, Michael Feiner, Jørgen Elmeskov, Yutaka Imai and Isabelle Joumard for valuable comments on earlier drafts. Special thanks go the Roselyne Jamin for technical assistance and to Nadine Dufour and Helen Maguire for technical preparation. The paper has benefited from discussions with numerous French experts, in the private sector, as well as in ministries and government agencies responsible for policy-making in this area.

2. Overall, government expenditures increased by more than 200 per cent in volume terms between 1970 and the beginning of the new millennium, 30 per cent more quickly than GDP itself. 
European Union average (Figure 1, Panel B). To a certain extent this comparison is influenced by the fact that some countries provide health, education and pension services through the private sector, whereas these are provided by the general government in France. Indeed, France spends the fifth highest share of GDP on merit goods (government services), with relatively high expenditure shares for education, health, services for the elderly and other family services (Table 1). However, even after excluding such spending France's public expenditure share remains one of the highest in the OECD (seventh).

Figure 1. Public expenditure Per cent of GDP
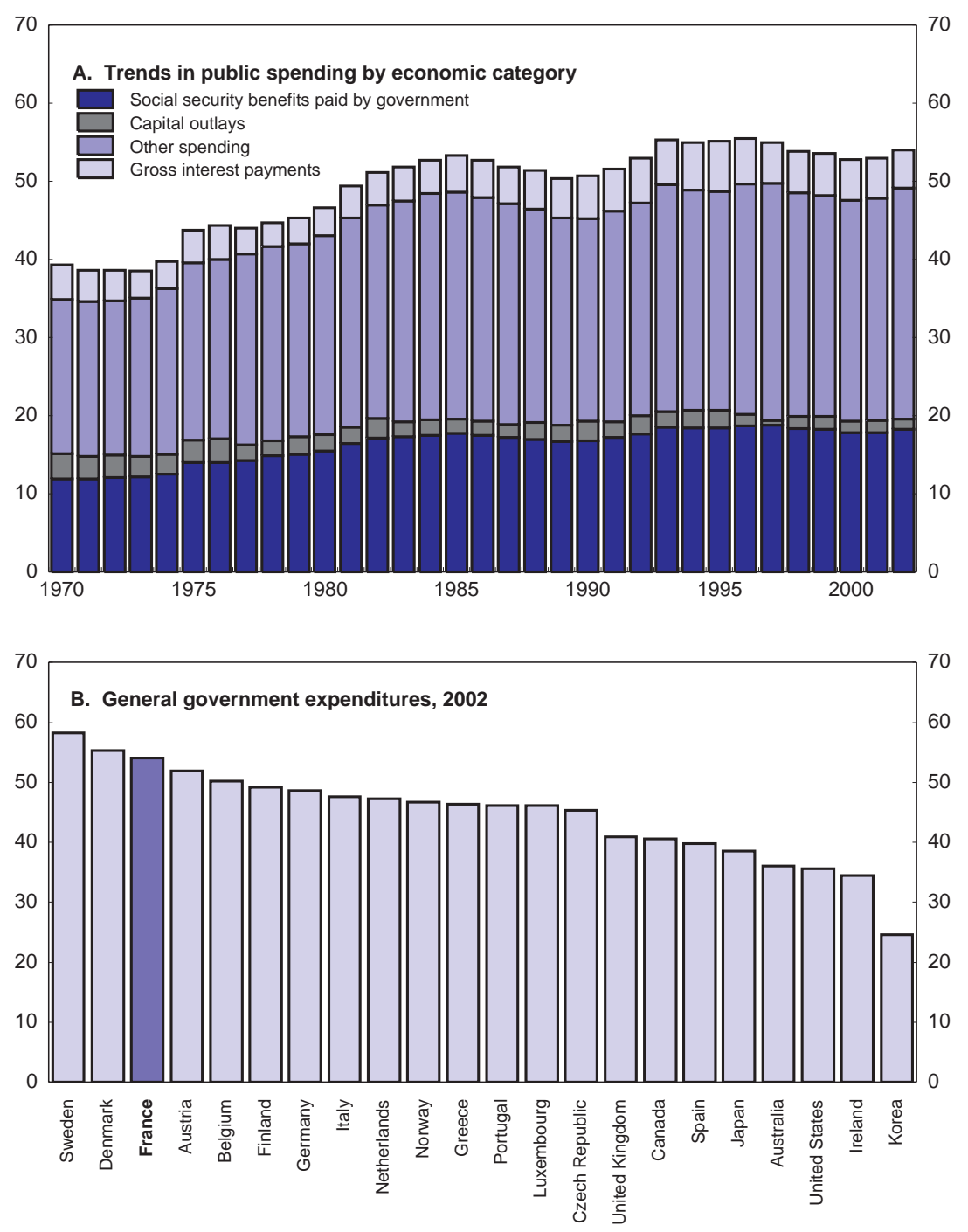

Source: INSEE and OECD.

4. The increase in spending mainly reflects rising primary expenditures (total spending less interest payments), which increased by 12 percentage points over the period in question to 50 per cent of GDP in 2002. More than half of the increase represents growing transfers, both as a result of rising unemployment and an expansion of both the coverage of and replacement rates in the social security systems (Figure 2). 


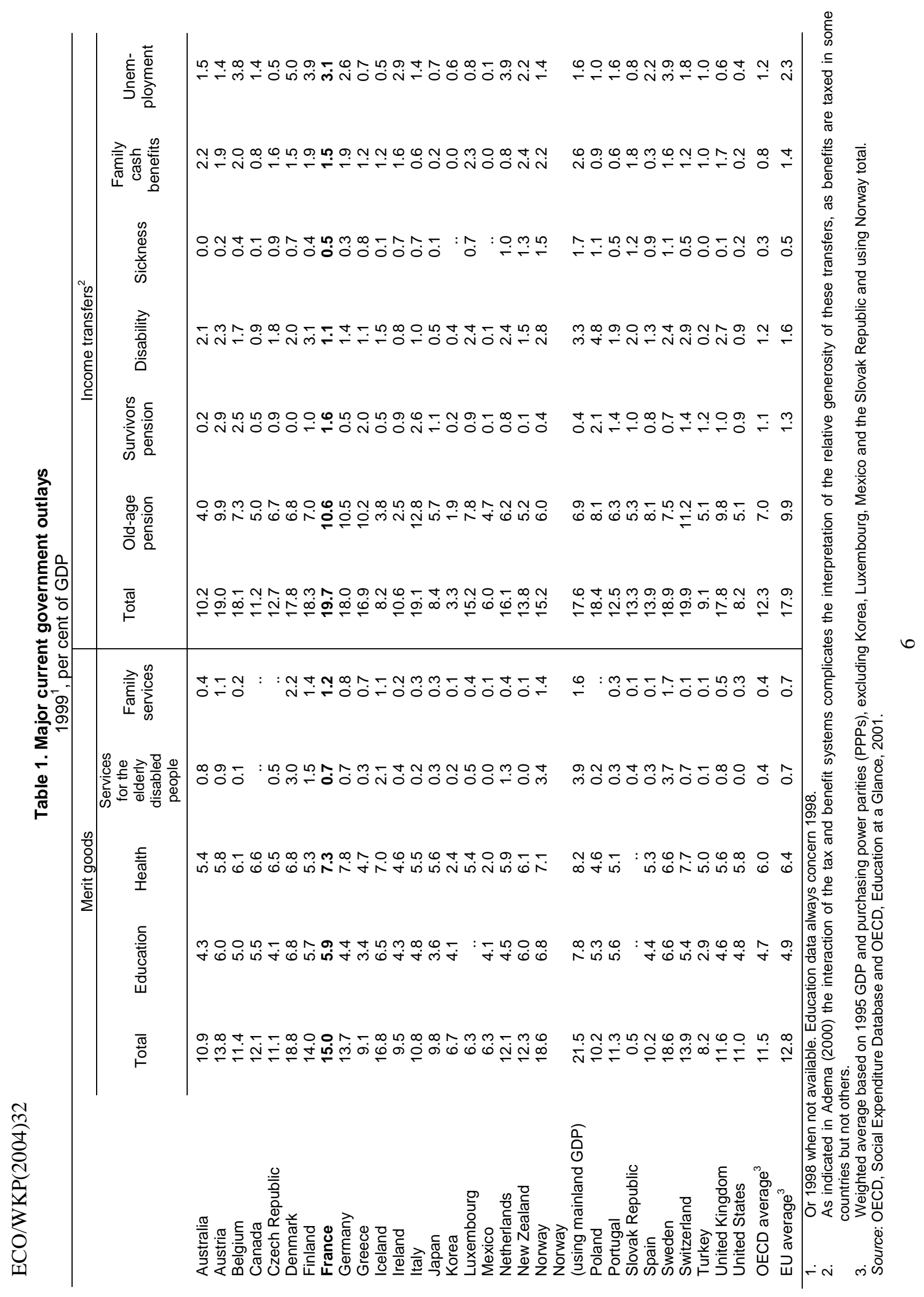


From a functional point of view, France spends more than any other OECD country on income transfers, with disbursements on old age and survivors' pensions and unemployment among the highest in the OECD. Currently, 62 per cent of French citizens live in households that receive at least one social benefit ${ }^{3}$ (Marlier and Cohen-Solal, 2000). Including pensions, raises this ratio to 80 per cent.

Figure 2. General government primary expenditure by economic category Per cent of GDP

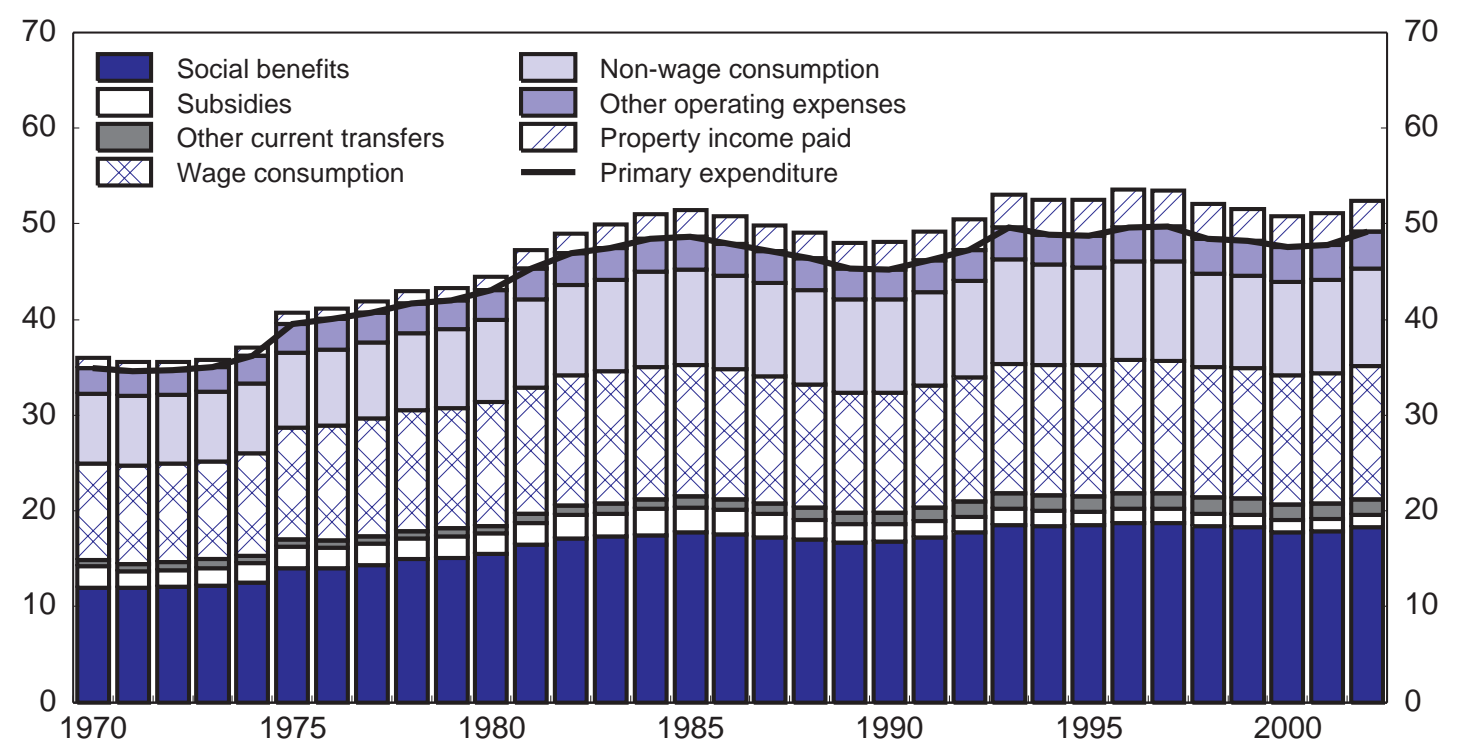

Source: INSEE and OECD.

5. As the role of the government expanded, public-sector employment also grew, from 3.7 to 5.9 million between 1970 and 2002, when it represented 24 per cent of total employment. As a result, the government wage bill yielded the second largest increase in spending shares, representing about one third of the total increase over the period. As deficits accumulated and interest rates rose, debt servicing charges also picked up, although during the 1990s these have declined both as a result of reduced debt levels and lower interest rates. National accounts data suggest that France spends about 1.3 per cent of GDP on subsidies of all sorts although if tax expenditures were included, this would be much more.

\section{The challenges ahead}

6. As elsewhere in the OECD, the ageing of the population will significantly determine both the nature of public expenditure and France's ability to finance it over the next several decades (see OECD, 2003, Chapter I). During the next 30 years, the population over 65 years of age is projected to increase by almost 75 per cent, while the working-age population (15-64) will be broadly stable or decline. ${ }^{4}$ As a result, the ratio of workers per person aged 65 or more is expected to decline from about 2.4 workers per person over 65 to 1.5 workers in 2030 and 1.3 workers by 2050. Taking into account the high incidence of early retirement and the official retirement age of 60 , the ratio of workers per retiree is expected to decline from 2:1 to 1:1 by 2030. In the absence of reforms to the pension system, ageing is expected to increase the pension system's funding shortfall by 8 per cent of GDP. Even assuming substantial improvements in labour force participation and unemployment rates, rising pension expenditures are expected to increase the deficit by 4.7 per cent of GDP (COR, 2001). Meanwhile, even if age-specific health expenditures rise

3. This compares with 52 per cent in the European Union considered a whole.

4. Calculations based on UN demographic projections, Commissariat Général du Plan (2002). 
only as fast as GDP, the purely demographic impact of ageing on health costs would be 1.9 per cent (Economic Policy Committee of the European Union, 2000) between now and 2050. If recent health cost trends were to persist this projected deficit would be very much larger.

7. The challenge of ageing for the state as an employer is even more acute. Over the next 15 years some 900 thousand workers are expected to retire or 41 per cent of State-sector workers. ${ }^{5}$ While this outflow represents a substantial opportunity to restructure the civil service by not replacing retirees in low priority areas, overcoming insider's opposition to any reduction in their numbers will not be easy.

8. If France is to make a successful transition to this more constrained fiscal environment, it is essential that policy makers develop tools that permit all areas of public expenditure to share the burden of creating the necessary fiscal room. Given the State Budget's shrinking share in total spending, it will be impossible to meet the spending pressures of the next several decades unless social security and subnational spending are restrained. Moreover, in order to prevent vested interests from blocking necessary reforms, efforts need to be made to clarify the roles of the State and the Social Partners in the governance of the Social Security system. In this regard, recent experience during which several reform efforts were withdrawn following widespread popular protests is not promising. The kind of extended consensus building that has preceded current efforts at pension reform might represent a model for the future, but its success has yet to be demonstrated. Whatever mechanism is used to achieve agreement, the need to avoid gridlock in the future is essential if authorities are to be able to make the sometimes difficult choices that will need to be made.

9. Finally, the ongoing reform of the State represents an important challenge. In this regard, the implementation of the new framework law for the State Budget (Loi Organique Relative aux Lois de Finances, LOLF) will be difficult. Reorienting the focus of the State Budget process towards outputs and policy objectives rather than just on the inputs into public service delivery involves substantial changes in "corporate" culture, which experience from other countries suggests are not easy to achieve. Here, the phase-in of new procedures by 2005 represents an ambitious schedule. Ultimately intangible factors impacting on the degree to which the spirit rather than the letter of the law is adopted and implemented may determine the extent that this innovation succeeds in increasing the efficiency with which public services are provided. Similarly, the results of the authorities' initiative to decentralise service provision and improve the matching between the financial and administrative responsibilities underlying programme delivery will determine to what extent the efficiency with which services are delivered can be increased. Moreover, if such steps are to help create fiscal room, mechanisms to ensure that savings are not spent elsewhere will need to be found.

\section{Budgetary process and arrangements across levels of government}

10. France is a unitary state, which nevertheless has several levels of sub-national government (collectivités territoriales): these include 36763 municipalities (communes), 100 departments and 26 regions (Table 2). In addition, the state has some 1400 extrabudgetary institutions, with activities ranging across commercial, educational and cultural domains (Box 1). While the municipalities and departments date back to the French Revolution, the regions were created in the mid-1980s. From the point of view of expenditure, the general government is comprised of the state budget, these sub-national groupings and the social security. Overall the State budget represents only 37 per cent of general government expenditure, while social security funds represent 45 per cent. The remaining 19 per cent is accounted for by the activities of sub-national governments (Figure 3$)^{6}$

5. Excluding public works employment and employees of State-owned enterprises. Calculations based on INSEE (2002) and Commissariat Général du Plan (2002).

6. This compares with an average of 30 per cent for OECD unitary states (OECD, 2003). 
Table 2. Organisation of the public sector in France

\begin{tabular}{|c|c|c|c|c|}
\hline \multirow[t]{9}{*}{$\begin{array}{l}\text { Public } \\
\text { sector }\end{array}$} & \multirow[t]{8}{*}{$\begin{array}{l}\text { General } \\
\text { government }\end{array}$} & \multirow[t]{4}{*}{$\begin{array}{l}\text { Central } \\
\text { govern- } \\
\text { ment }\end{array}$} & State & $\begin{array}{l}\text { Directions d'administration centrale (Central administrative } \\
\text { directorates) and Services à compétence nationale } \\
\text { (Administrations under national competence). The main } \\
\text { responsibilities of the Directions are analysis and projections of } \\
\text { public needs; draft of regulations and laws, including the Budget; } \\
\text { management, co-ordination and supervision of the local } \\
\text { administrative branches of the state; evaluation of the impact of } \\
\text { public policies impacts. The responsibilities of the services à } \\
\text { compétence nationale are: the legal system, management of } \\
\text { National museums, the fight against illegal immigration, and } \\
\text { production of specialised studies. They also ensure the provision } \\
\text { of numerous operational services. } \\
\text { Services déconcentrés de l'État (local services of the state) are } \\
\text { the purview of the préfets (prefects) who are directly appointed } \\
\text { by the government. They are responsible for the implementation } \\
\text { of all national civilian policies (education, culture, agriculture, } \\
\text { etc.), and for police. }\end{array}$ \\
\hline & & & \multirow[t]{3}{*}{$\begin{array}{l}\text { Other entities } \\
\text { of the central } \\
\text { government }\end{array}$} & $\begin{array}{l}\text { Etablissements publics à caractère administratif, EPA (public } \\
\text { agencies with a service and administrative vocation), i.e. the } \\
\text { securities commission, the national school of administration } \\
\text { (COB -Commissions des opérations de bourse, ENA -Ecole } \\
\text { nationale d'administration, etc.). }\end{array}$ \\
\hline & & & & $\begin{array}{l}\text { Établissements publics à caractère scientifique et technologique } \\
\text { EPST (public agencies with a scientific and technological } \\
\text { vocation), i.e. the CNRS, national research institute, etc). }\end{array}$ \\
\hline & & & & $\begin{array}{l}\text { Établissements publics à caractère scientifique culturel and } \\
\text { professionel, EPSCP (universities, national museums, etc). }\end{array}$ \\
\hline & & \multirow{2}{*}{$\begin{array}{l}\text { Regional } \\
\text { and local } \\
\text { govern- } \\
\text { ments }\end{array}$} & $\begin{array}{l}\text { Local } \\
\text { administrations }\end{array}$ & $\begin{array}{l}\text { They include } \\
\text { municipalities (communes), departments } \\
\text { (départements), regions (régions) and various entities } \\
\text { responsible for local co-operation initiatives. }\end{array}$ \\
\hline & & & $\begin{array}{l}\text { Other local } \\
\text { entities }\end{array}$ & $\begin{array}{l}\text { Locally financed non-market entities (for example, primary and } \\
\text { high schools, Chambers of commerce, etc.). }\end{array}$ \\
\hline & & \multirow[t]{2}{*}{$\begin{array}{l}\text { Social } \\
\text { security }\end{array}$} & $\begin{array}{l}\text { Social } \\
\text { insurance } \\
\text { schemes }\end{array}$ & $\begin{array}{l}\text { They include } 37 \text { mandatory schemes, or régimes, each } \\
\text { managing at least one of the following classes of risks: } \\
\text { healthcare (both medical treatments and wage replacing per } \\
\text { diem sickness benefits); retirement and survival (including } \\
\text { complementary regimes); family and maternity; housing benefits; } \\
\text { poverty and social exclusion. In addition, the special financing } \\
\text { funds (FSV, FFR, etc.) are included. } \\
\text { Though administratively and financially more independent, the } \\
\text { UNEDIC (Union nationale inter-professionnelle pour l'emploi } \\
\text { dans l'industrie et le commerce), which is responsible for } \\
\text { unemployment insurance, is also part of the social insurance } \\
\text { system in the national accounts classification. }\end{array}$ \\
\hline & & & $\begin{array}{l}\text { Entities } \\
\text { administered } \\
\text { by the social } \\
\text { insurance } \\
\text { schemes }\end{array}$ & Example, public hospitals. \\
\hline & $\begin{array}{l}\text { Large } \\
\text { publicly } \\
\text { owned } \\
\text { enterprises }\end{array}$ & \multicolumn{3}{|c|}{$\begin{array}{l}\text { RFF, railways infrastructure, SNCF, railway service, ADP, Parisian airports, RATP, Paris public } \\
\text { transport network, France Telecom, La Poste, EDF/GDF, energy network. These entrerprises have } \\
\text { status of Établissements publics à caractère industriel et commercial, EPIC (public agencies with } \\
\text { an industrial and commercial vocation). }\end{array}$} \\
\hline
\end{tabular}

Source: OECD. 


\section{Box 1. Fiscal relations between levels of government}

In France, both the central government and the local authorities comprise several levels of governments (see Table 2).

\section{Central government}

The central government operates at three levels: central services, local services of the central government (services déconcentrés de l'État), and Public establishments (établissements publics de l'État). Overall, State employees represent 73 per cent of all public-sector employees with most of them employed at the level of administrative districts.

The central services are provided by and operate under the direct authority of Ministers, deputy Ministers and State Secretaries, and mainly provide technical support functions.

Local state services are provided by administrative districts (circonscriptions administratives), which differ from the local governments (collectivités territoriales, see below) in that, while the former are run by prefects, who are directly appointed by the government, the latter are autonomous entities, administered by locally elected assemblies.

The prefects channel all relations between the state and the local authorities. They have the power to review local government by laws and are responsible for the implementation of all national civilian policies (culture, agriculture, etc.) and the police. In addition, they help monitor the application of national regulations and community services. Finally, they can order modifications to sub-national budget proposals if they do not comply with budgetary rules. In municipalities, however, for certain functions, such as those concerning vital statistics, the state is represented by the mayor.

Public Establishments (of which there are 1400) are moral persons placed under separate public code. Although they enjoy a certain degree of financial and managerial autonomy, they report to at least one ministry which appoints the management, supervises strategic decisions and decides upon the allocation of subsidises. There are different kinds of Public Establishments involved in activities like education, $R \& D$, cultural promotion, social protection and solidarity, work and employment, construction, urbanism and environment. These activities are all part of the general government. A wider definition of the public sector also comprises a number of large publicly owned enterprises involved in public transport, the postal network and energy.

\section{Local governments}

There are also three levels of local governments: municipalities (communes), departments (départements), and regions (régions).

The municipalities are responsible for local matters such as town planning, municipal infrastructure, subsidised housing, local public services (waste treatment, water, public transport, lighting), health and social services, education (operation of primary public schools, their construction and their maintenance), cultural affairs (museums and theatres), security, public order, hygiene, aid to employment and to business (subject to EU competition rules).

The departments focus mainly on departmental roads and the management of everyday affairs, such as welfare benefits, health care benefits, job placement for the unemployed, secondary education, local transports.

Finally, the regions, are mainly responsible for land-use planning and economic development: vocational training; secondary education; rail and waterway transport; and aid to development.

In its role as the administrator of the local governments' receipts, the State collects local taxes, a mission that it accomplishes relying upon its own information network. While the State is committed to provide local governments with the full extent of the budgeted revenue envelope it does this at a fee. Own local tax receipts still represent a small proportion of total local tax revenues. 


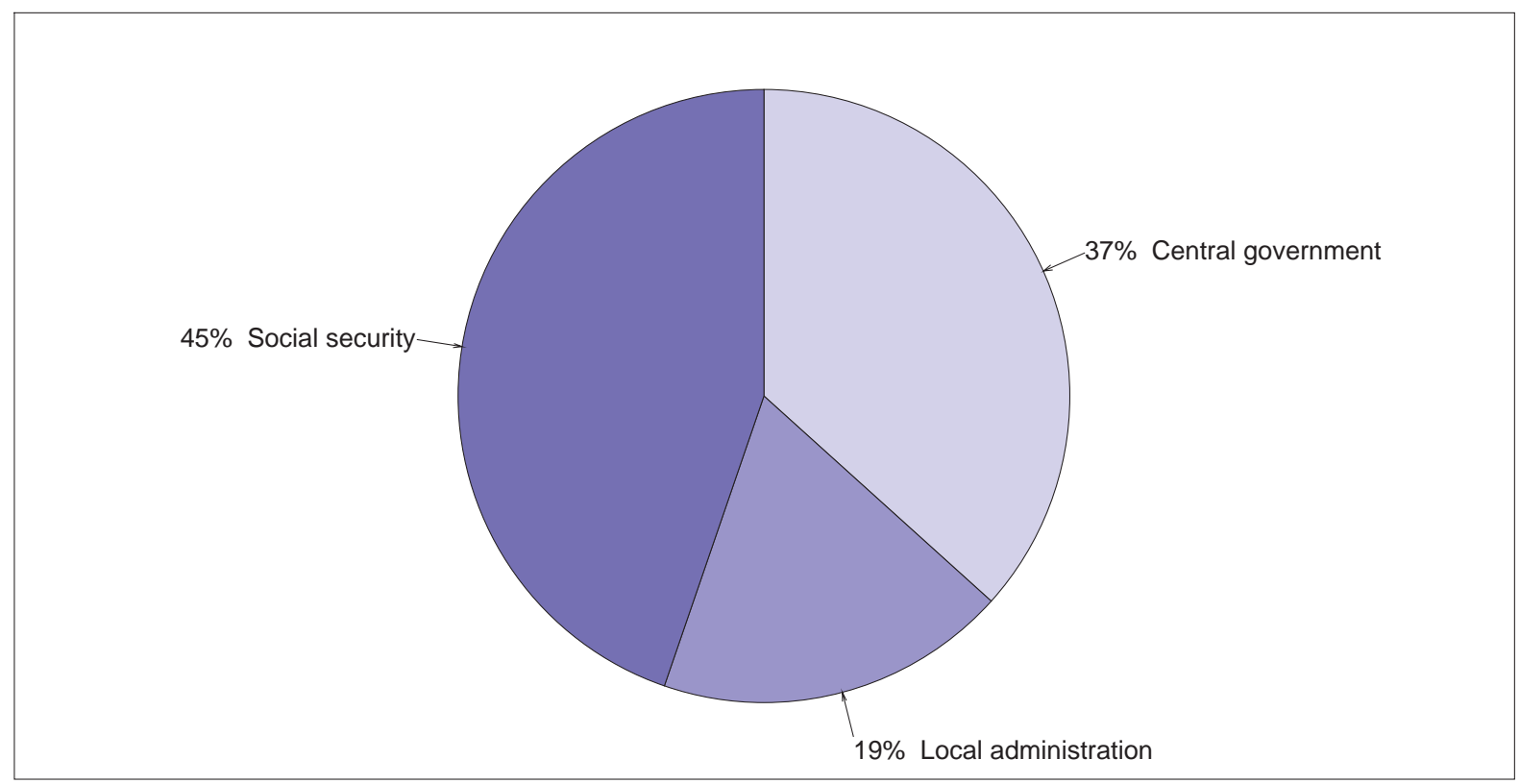

Source: Ministry of Economy, Finance and Industry and OECD.

\section{The State budget}

11. The State budget is annual, although the obligation to produce a three year budget projection in the context of the Stability and Growth Programme has introduced a multi-year element to the process. The elaboration of the Budget begins the year before with the closing of the previous year's accounts. The Ministry of Finance (Ministère de l'Économie, des Finances et de l'Industrie, MINEFI) proposes to the cabinet a very aggregated budget based on a preliminary set of spending priorities and a macroeconomic framework (Table 3). Documentation is streamlined and focuses on functional priorities, rather than detailed spending chapters. Once the broad lines of the budget are approved by the cabinet, including global revenue and expenditure envelopes, the Ministry of Finance proceeds to elaborate a more detailed budget, negotiating with line ministries and the cabinet concerning allocations between ministries (cadrage budgétaire). Once approved by cabinet, this draft budget (Projet de loi de finance, PLF) is presented to parliament -- no later than early October.

12. The Budget itself is relatively detailed and is supported by a variety of additional documents, the so called bleus and jaunes (blue and yellow papers), which are appended to it. The jaunes are usually distributed after the PLF but early enough to contribute to parliamentary discussions. They consist of policy oriented discussions of various topical issues. Thus, in 2003, areas covered included the social role of the state, national defence, and audio-visual broadcasting policies. The bleus are distributed with the PLF and provide technical information concerning:

- the macroeconomic forces shaping the government's economic forecast;

- expected fiscal and quasi fiscal revenues (including tax expenditures), distinguishing between revenues based on unchanged policies and the impact of new measures;

- transfers and earmarked revenues allocated to specific extra budgetary funds; 
- $\quad$ separate annex budgets for six entities dependent upon the state, most notably that of agriculture social fund (Budget annexe des prestations sociales agricoles, BAPSA);

- finally, an outline of expenditures by individual chapters (of which there are 840), each one distinguishing between pre-existing and new spending appropriations.

13. Parliamentary debate of the budget passes through three readings and must be completed before the 31st of December. Historically, Parliament has had only very limited powers to amend the Budget. With the introduction of a new framework law in 2001 (see below), Parliament may now propose amendments to spending within Budgetary missions (large areas regrouping government objectives) but not between them. As a consequence, it cannot revise the total level of spending and cannot reallocate money from large spending items such as defence to education, for example. Nevertheless, the ability to affect allocations within missions is an important new power.

14. The French budgetary system includes a tight treasury function, with a complex and relatively heavy process of ex ante and ex post controls conducted by various departments within the Ministry of Finance. The process includes a sharp distinction between the person who authorises an expenditure commitment and the one who authorises payment. Spending authorisations are made by line ministry spending officers (ordonnateurs). Before such authorisations may be executed they must be approved ex ante by the financial controllers employed by the Ministry of Finance but physically located in ministries. The expenditure is subject to a third verification by Ministry of Finance accountants prior to authorisation of payment. Finally the whole process is subject to ex post audit by the General finance inspectorate (Inspection générale des finances, IGF) and also the National Auditor (Cour des Comptes). Moreover, the National Auditor provides regular examinations of the effectiveness of government programmes.

15. In the course of the budgetary year, the Ministry of Finance has significant, although not unrestricted, powers to revise budgetary allocations as needed. It enjoys wide discretionary powers to transfer appropriations within and across line ministries, provided that this does not change the nature and the amount of the budget. The Ministry of Finance (acting for the government) can freeze credits awarded to any given Ministry and has the power to formally declare a given programme "without object", an action that entails the immediate cancellation of any related spending appropriations. However, the total of such cancellations cannot reduce total expenditures by more than 1.5 per cent of initially authorised credits, unless parliament passes a revised budget (Loi de finances récapitulative), which can also be used to authorise additional expenditure. All in all, approximately 20 per cent of Budget chapters are modified in this way during the course of a year by government decisions (Chevauchez, 2002). 
ECO/WKP(2004)32

Table 3. Preparation of the State budget

\begin{tabular}{|c|c|c|c|}
\hline PHASE & $\begin{array}{l}\text { REFERENCE } \\
\text { PERIOD }\end{array}$ & OBJECTIVES & ACTIONS UNDERTAKEN \\
\hline \multicolumn{4}{|c|}{ A. Global budgetary strategy } \\
\hline Projections & $\begin{array}{l}\text { December }(n-2)-\text { mid } \\
\text { March }(n-1)\end{array}$ & $\begin{array}{l}\text { To finalise multiyear }(n+3) \\
\text { budget commitments with the } \\
\text { European Commission based } \\
\text { on expected macroeconomic } \\
\text { developments; } \\
\text { To review budgetary needs for } \\
\text { the year } n \text { on the basis of } \\
\text { current policies (budgets de } \\
\text { reconduction). }\end{array}$ & $\begin{array}{l}\text { Multiyear budget programme prepared jointly by the } \\
\text { Forecasting Directorate (Direction de la Prévision) } \\
\text { and the Budget directorate (Direction du Budget) and } \\
\text { sent to the European Commission; } \\
\text { Sectoral divisions of the Budget Directorate prepare } \\
\text { sector specific spending dossiers for the year n. } \\
\text { Budget Directorate transmits a budget summary note } \\
\text { to the Economy Minister. }\end{array}$ \\
\hline $\begin{array}{l}\text { Framework letter } \\
\text { (Lettre de } \\
\text { cadrage) }\end{array}$ & Mid March-mid April & $\begin{array}{l}\text { To set out budgetary policy for } \\
\text { the year } n \text { in light of the } \\
\text { announced macro economic } \\
\text { projections. }\end{array}$ & $\begin{array}{l}\text { Inter-ministerial debate } \\
\text { After consultation with the Minister of Finance, the } \\
\text { Prime Minister signs a framework letter and sends it } \\
\text { to line Ministries }\end{array}$ \\
\hline \multicolumn{4}{|c|}{ B. Budget definition } \\
\hline First stage & Mid April-May & $\begin{array}{l}\text { To allow Ministries to express } \\
\text { and discuss their priorities; } \\
\text { To allow the Direction du } \\
\text { budget to evaluate such } \\
\text { priorities in light of the } \\
\text { government's global priorities. }\end{array}$ & $\begin{array}{l}\text { Ministries' representatives meet with the Budget } \\
\text { Directorate's vice-directors who are responsible for } \\
\text { negotiating specific budgetary allocation issues } \\
\text { (Conférences budgétaires). }\end{array}$ \\
\hline $\begin{array}{l}\text { Arbitration } \\
\text { (Arbitrage) }\end{array}$ & June & $\begin{array}{l}\text { To set out a list of unsettled } \\
\text { spending issues; } \\
\text { To eliminate as many } \\
\text { elements of disagreement as } \\
\text { possible. }\end{array}$ & $\begin{array}{l}\text { Based on the of the outcomes of the Conférences } \\
\text { Budgétaires, the Budget directorate transmits an } \\
\text { arbitration document (dossier d'arbitrages ) to the } \\
\text { Finance Minister; } \\
\text { The Minister of Finance discusses unsettled issues } \\
\text { bilaterally with the other Ministries. }\end{array}$ \\
\hline $\begin{array}{l}\text { Ceiling letters } \\
\text { (Lettres-plafonds) }\end{array}$ & July (first half) & $\begin{array}{l}\text { To summarise the terms of the } \\
\text { various arbitration agreements } \\
\text { concluded; } \\
\text { To define each Ministry's } \\
\text { budgetary means. }\end{array}$ & $\begin{array}{l}\text { The Ministry of Finance sends a detailed ceiling letter } \\
\text { to his colleagues. }\end{array}$ \\
\hline Second stage & Mid July-September & $\begin{array}{l}\text { To fix final spending details; } \\
\text { To assess budgetary } \\
\text { revenues; } \\
\text { To calculate the budget } \\
\text { balance; } \\
\text { To draft Ministry specific } \\
\text { budget documents; } \\
\text { To draft the general budget } \\
\text { (PLF, projet de loi de finances) }\end{array}$ & $\begin{array}{l}\text { Ministries' representatives have supplementary } \\
\text { (mainly technical) meetings with the Budget } \\
\text { Directorate's representatives (Conférences } \\
\text { Budgétaires de "deuxième phase); } \\
\text { Technical/legal work within the Ministry of Economy } \\
\text { focussed on the revenue side; } \\
\text { Finalisation of budget documentation. }\end{array}$ \\
\hline $\begin{array}{l}\text { Official } \\
\text { presentation }\end{array}$ & End-September & To adopt and diffuse the $P L F$ & $\begin{array}{l}\text { Council of Ministries adopts the budget, } \\
\text { PLF is presented to the press. }\end{array}$ \\
\hline $\begin{array}{l}\text { Submission to } \\
\text { Parliament } \\
\text { (Saisine } d u \\
\text { Parlement) }\end{array}$ & October-December & $\begin{array}{l}\text { To ensure that Parliament } \\
\text { receives, discusses and votes } \\
\text { the } P L F\end{array}$ & $\begin{array}{l}\text { The PLF is deposited in the office of the President of } \\
\text { the Assemblée Nationale before the first Tuesday of } \\
\text { October and it is thereafter transmitted to the Sénat. }\end{array}$ \\
\hline $\begin{array}{l}\text { Submission to the } \\
\text { Constitutional } \\
\text { Council } \\
\text { (Saisine du } \\
\text { Conseil } \\
\text { Constitutionnel) } \\
\end{array}$ & October-December & $\begin{array}{l}\text { To ensure that the } P L F \\
\text { respects legal requirements }\end{array}$ & $\begin{array}{l}\text { The PLF is submitted to the scrutiny of the } \\
\text { Constitutional Council. }\end{array}$ \\
\hline Publication & December & $\begin{array}{l}\text { To publish the Loi de finances } \\
\text { on the Official Journal. }\end{array}$ & $\begin{array}{l}\text { Publication to be done before the } 31 \text { of December of } \\
\text { the year } n-1 \text {. }\end{array}$ \\
\hline
\end{tabular}




\section{Sub-national governments}

16. Budgetary rules at the sub-national level are much more restrictive. The regions, departments and municipalities, must present balanced budgets (équilibre réel). In practical terms, this means that their operating budgets (section de fonctionnement) must be in surplus and this must be large enough to fully cover planned capital expenditures (section d'investissement), and, except for municipalities with fewer than 3500 citizens, projected debt payments during the year (interest payments, depreciation costs and expected realisations of contingent liabilities). The fiscal year for sub-national budgets is the same as for the State, but local governments do not need to adopt their budget until the end of March (well into the current fiscal year).

17. The State exercises the treasury function for local governments, providing them with equal monthly instalments according to their initial budgets. Local taxes are collected by the State. Although local governments have some limited ability to choose rates applied to some tax bases, own revenues account for less than 5 per cent of all revenues. Payments are made irrespective of how tax revenues are evolving. Moreover, local authorities are not free to manage their non-tax revenues, but must deposit them in State Treasury accounts operated by the Bank of France. Their expenditures are subject to a similar $e x$ post and ex ante financial control process, except that the expost audit function is conducted by the regional audit courts (Chambres régionales des Comptes). Prefects can, based on a finding of the regional audit court, require that missing expenditures be inserted into the budget law.

18. Historically these restrictions have ensured the overall balance of the sub-national level of government.

\section{Social protection}

19. The draft Social security budget (Projet des lois de financement de la sécurité sociale, PLFSS) sets forth the expected revenues and expenditures of the various healthcare, pension and social assistance funds (Box 2). The PLFSS is presented to parliament immediately after the draft State Budget and is based on the same underlying macroeconomic and revenue assumptions. The two budgets are debated more or less simultaneously so as to emphasise their interdependence and the tradeoffs that there may be between them. In this respect the PLFSS, which was introduced in 1996, is a recent innovation that seeks to impose a degree of parliamentary oversight over social security expenditures that did not exist previously.

\section{Box 2. The social security system}

\section{Structure of the social security system}

Most of the French social security system is administered by extrabudgetary funds. There are some 37 social security schemes (régimes), which include general and professional health insurance, workman's compensation and invalidity insurance; old-age and survivors insurance and social assistance. In addition an unemployment insurance scheme and some elements of active labour market policy are run by the UNEDIC (Union nationale inter-professionnelle pour l'emploi dans l'industrie et le commerce).

Compulsory basic insurance is provided by three general regimes and 28 special firm- or sector-specific regimes, the most important of which are those covering the public sector and many state-owned firms. Most of the special schemes deal only with retirement income, although four also cover healthcare. ${ }^{1}$ Three broadly based and widely subscribed regimes are:

CNAVTS (Caisse nationale d'assurance vieillesse des travailleurs salariés) administers the mandatory pension contributions of most dependent employees and manages the old age targeted social assistance programmes.

CNAMTS (Caisse nationale d'assurance maladie des travailleurs salariés) administers health, maternity, invalidity, professional sicknesses, death and on the job accidents insurance for broadly the same categories of employees. Moreover, it co-ordinates the medical verification system and participates in the organisation of health prevention campaigns. 
CNAF (Caisse nationale des allocations familiales) is responsible for the administration of most social assistance programmes, including: housing benefits, anti poverty programmes, such as the guaranteed minimum revenue (Revenu minimum d'insertion, RMI).

Of these only CNAF provides universal coverage. The CNAMTS covers about 84 per cent of individuals, while the general pension scheme covers less than half of pension benefits.

In addition there are so-called complementary old-age regimes, which are organised along professional lines (clerks, managers, for example). ${ }^{2}$ Despite their name, these regimes are compulsory. Unlike the general regime they are not subject to relatively low contribution and benefit ceilings, thereby allowing combined pensions to achieve significant levels.

Although contributions are collected locally, all collected revenues are integrated in a special account at the Central Fund for Social Security (Agence centrale des organismes de sécurité sociale, ACOSS), which provides the treasury services across-schemes and distributes resources.

\section{Interactions between social security and the State}

The regimes' administrative autonomy from the State varies widely. The three nation-wide regimes are state entities (Établissements publics). Thus while they are outside the State administration, their supervisory board is appointed by the government, as are several members of their administrative boards (the others being appointed by representatives from the trade unions and the employers associations). Similarly, the special public-sector regimes (including those of several state-owned enterprises) are under the direct responsibility of the state and their accounts are integrated in the State Budget, or directly into the firms' balance sheets. The employers' and complementary regimes operate under private-sector law and enjoy more autonomy.

1. The special regimes for agents of SNCF and RATP cover both risks, while the Fonctionnaires de l'État contribute to the general regime for healthcare and to their own pension regime.

2. Five of the 28 special regimes manage both the basic and the complementary component of their subscribers' pensions.

20. The PLFSS is elaborated by the Ministry of Health in close cooperation with the Ministry of Finance before being decreed by the Cabinet. In contrast to the State Budget, it has no associated balance because the range of expenditure programmes (obligatory schemes with more than 20000 subscriptors) and revenues (all of the regimes and organisms that contribute to their financing) are not identical. The budgets allocated to the pension regimes and, to a lesser extent, the social assistance regimes pose relatively few technical challenges. The parameters that determine their revenues (contribution rates, earmarked revenues, transfers from the State Budget) and their expenditures (benefit rates, eligibility rules) are determined by the government. As a result, the authorities have in their hands not only the tools necessary to predict both expenditures and revenues, but also the ability to adjust parameters so as to ensure financial sustainability. The Healthcare budget is more complicated (see OECD, 2001 for a fuller discussion of the French health care system). Although tariffs and unit costs are also defined by the government, the quantities supplied, and therefore overall costs, are largely unconstrained. Parliament seeks to exercise some influence by establishing a national health spending target (Objectif national des dépenses d'assurance-maladie, ONDAM), within the PLFSS. With the exception of the hospital sector, where the government has the ability to impose a binding budget constraint, the ONDAM is not a cap on reimbursements. For the ambulatory care (private fees, prescriptions, per diem sickness benefits) and medical-social sectors (the elderly, maladjusted children, handicapped adults) the ONDAM specifies spending targets that are consistent with financial stability and defines policy priorities. A combination of the non-binding nature of the ONDAM and unrealistic targets has, over the years, resulted in actual outturns systematically exceeding the ONDAM by large margins.

21. The budget of the UNEDIC, the umbrella agency responsible for unemployment insurance, is not covered by the PLFSS. The UNEDIC operates as a delegated public service and has much more autonomy than the other social security agencies in determining both contribution rates and benefits that it pays. 
Union and business representatives, who are equally represented on its board (organisational representations were last fixed in the mid 1980s), meet biannually to agree proposals on these rates. The board's propositions are then presented to the government, which, if it agrees, passes a decree giving them the force of law. While not a voting member of the UNEDIC, the necessity of having its agreement to any accord means that generally the government's voice is heard in discussions and only rarely has the government imposed an agreement on the social partners. Moreover, the UNEDIC provides additional services for the State, such as extended unemployment insurance benefits to the long-term unemployed, reimbursed by the State Budget.

22. The financial relationship between the State Budget and the social security funds is complex. Approximately two-thirds of social security funding comes from social security contributions levied on payrolls $^{7}$ and one-sixth comes from a special income $\operatorname{tax}^{8}$ (Contribution sociale généralisée, CSG) that is levied on a wider base including income from capital. In 2001, indirect and direct State Budget transfers to the social security system represented about 125 billion euros or more than 8 per cent of GDP, not including the 25 billion euros spent on public servant pensions, which do not pass through the social security regimes. Of this amount, the State Budget makes a direct contribution of 35 billion euros (2.4 per cent of GDP): 10 billion euros to the various organisms of the social security system; 21 billion euros to compensate the social security schemes for programmes that they administer for the State; and 4 billion in direct subsides to compensate for the deficits of the regimes of various state owned enterprises (Box 3 ). The remaining 90 billion euros (6 per cent of GDP) are distributed in the form of earmarked revenues from a wide range of sources including the CSG, excise taxes and duties (levied on products such as tobacco, alcohol and gasoline). Two thirds of this goes directly to the social security regimes and $1 / 3$ goes to the special funding schemes. Of this last third, about half is paid to reimburse the social security regimes for the reduced revenues from special payroll tax reductions instituted in effort to reduce the cost of low-paid labour and to offset costs associated with the 35 hour workweek. Finally, substantial additional money is channelled to and between the social security funds through various special vehicles. In 2002, the total of these transfers and additional revenues from the special funding schemes amounted to 44 billion euros (about $2 \frac{1}{2}$ per cent of GDP).

23. Both the collection of revenues and distribution of benefits of the various social security funds is coordinated by a Public Enterprise, the Central Agency of the social security schemes (Agence centrale des organismes de sécurité sociale, ACOSS). Since 1996, the ACOSS operates as an independent agency under contract to the State, with specific objectives and mutual obligations specified in a contract (convention), the most recent of which is to run for the period 2002-2005. The ACOSS in turn signs similar contracts with the 100 plus regional agencies responsible for collecting social security contributions (known collectively as URSAFF, Union de recouvrement des cotisations de sécurité sociale et d'allocations familiales) and the 37 funds charged with distributing benefits. The ACOSS manages its own treasury function, although this is monitored on a monthly basis by the Treasury Department of the Ministry of Finance. Overruns are financed by loans from the state-owned "Caisse des dépôts". In contrast to the other social security schemes, the UNEDIC maintains its own parallel collection and benefit distribution system. It performs its own treasury function and relies on the private banking sector for cash management and borrowing operations alike, but as a special entity recognised as "pursuing a mission of general interest", its liabilities are guaranteed by the state, which on several occasions has been called upon to cover its accumulated debts.

7. The share of social security contributions levied from payrolls represents about 50 per cent of the funding of the health system, 59 per cent of that of the family and social assistance regime and 71 per cent of the old age pension system.

8. The CSG represents 34.5 per cent of healthcare revenues and 20.7 per cent of those destined for the social assistance system. The old-age pension system does not receive revenues from the CSG. 


\section{Box 3. Special social security financing funds}

The accumulated deficits of some social security funds, and government programmes promoting various policy objectives affect the overall balance of the social security funds. In response, the authorities have created a variety of special funds, whose revenues are assured by the General Social Security Contribution (Contribution sociale généralisée, CSG), excise taxes and privatisation revenues to supplement the earmarked revenues of the social security system. Some of the most important of these are the following:

- The old age solidarity fund (Fonds de solidarité vieillesse, FSV) was created in 1993 and is financed by the overall budget of the family assistance regime and certain taxes, notably a 2 per cent surcharge on capital revenues (part of the base for the CSG) and the surplus of the social solidarity contribution paid out by firms (Contribution sociale de solidarité des sociétés). It funds assistance-related aspects of old age expenditure, like the minimum pension (minimum vieillesse) and other special old age benefits. As of 1996, the fund for the amortisation of the social debt (Caisse d'amortissement de la dette sociale, CADES) has taken on some of these activities.

- $\quad$ The Retirement Reserve Fund (Fonds de réserve pour les retraites, FRR) was created in $1999^{1}$ is supposed to be funded from privatisation revenues and the same taxes and surpluses that finance the FSV. It is hoped that by 2020 it will accumulate some 153 billion euros (10 per cent of GDP in 2002) which can then be gradually disbursed in order to smooth the pension-related costs from the ageing of the population (see OECD, 2001).

- The Fund to Finance the Reform of Enterprises' Social Charges (Fonds de financement de la réforme des cotisations patronales de sécurite sociale, FOREC), was created in 2000 as a means to offset the revenue losses incurred by various regimes due to the reductions in social charges associated with the 35 hours legislation.

- In addition, there are several smaller special funds, namely the Fund for the financing of special assistance allowances to the elderly (Fonds des financement de l'allocation personnalisée d'autonomie, Fonds APA), the Solidarity Fund (Fonds de solidarité), the Asbestos- workers early retirement Fund (Fonds de cessation anticipée d'activités des travailleurs de l'amiante, FCAATA) and the agriculture work accident fund (Fonds commun des accidents du travail agricole, FCATA).

1. Enabling legislation was passed in 1999 but the directive actually creating the fund was not issued until 2001 .

24. Ex post auditing of the social security regimes is provided by the National Auditor (Cour des Comptes), which issues regular reports on the legal execution of the budgets of the social security, but also provides more analytical reports on the efficiency with which their expenditures were made, an activity that is consuming an increasing share of its energies. Moreover, the regimes are subject to constant oversight from the Ministries of Health; Family and Social Affairs; and Finance. Day-to-day operations are supervised by the social affairs general inspectorate (Inspection générale des affaires sociales). Finally an end of year report (loi de règlement) outlining the outturn of the previous year's social security budget is reported to parliament prior to the presentation of the budget for the coming year.

\section{Policies to strengthen public expenditure management}

25. Given the strong financial pressures facing public expenditure in the medium to long term, the authorities' capacity to direct, successfully plan, and implement a medium-term spending strategy will be of increasing importance. Moreover, the tools available to public officials to help them arbitrate between competing demands will be crucial. While steps are already being taken to strengthen structures in both of these areas, more can be done. The following paragraphs seek to identify the directions for reform susceptible to improve policy makers' ability to exercise fiscal control effectively, while at the same time continuing to offer an appropriate range of services to their citizens in a cost-effective way. 


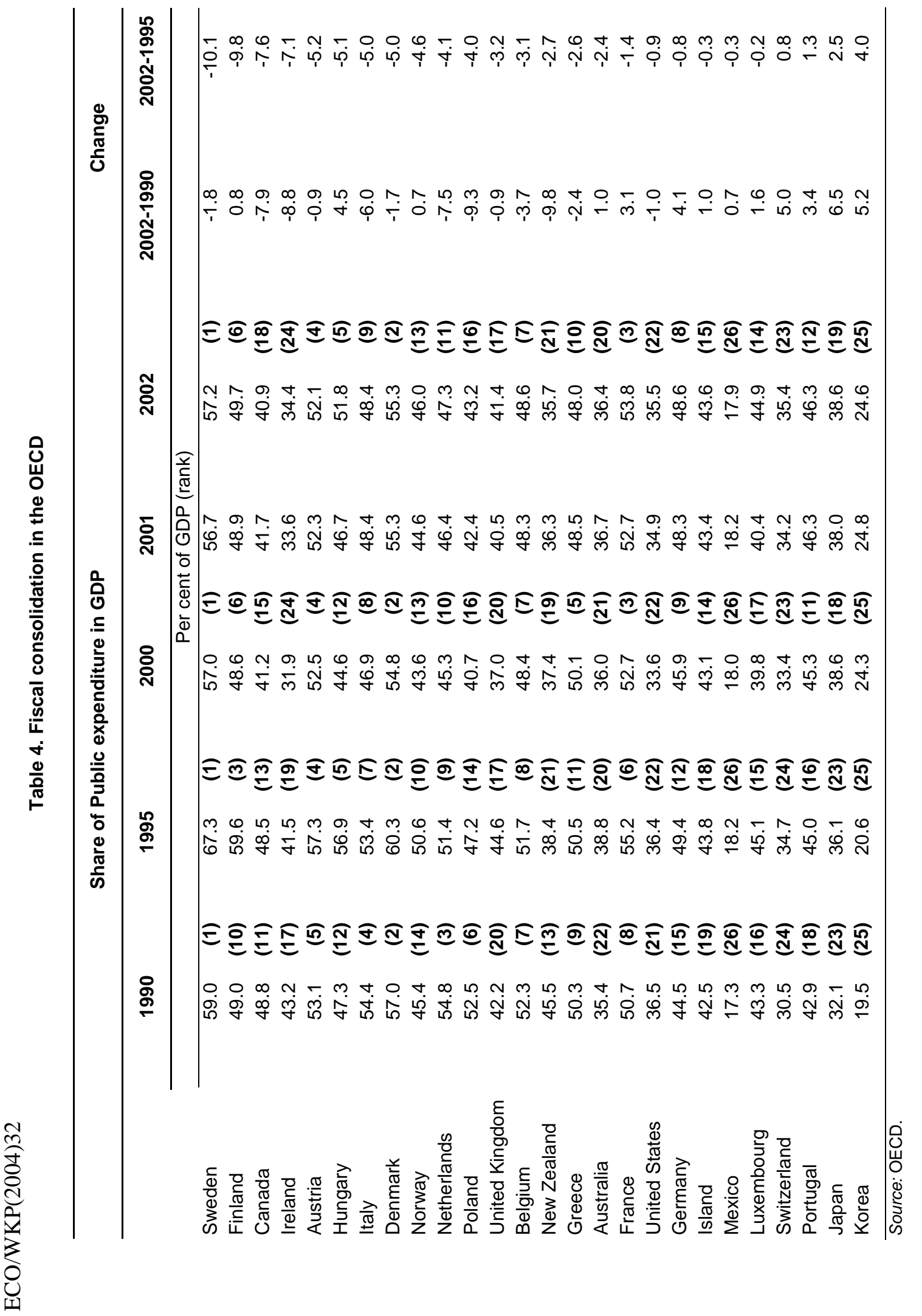




\section{Improving the authorities' control over expenditure}

26. The problems posed by increasing spending pressures as the population ages and the economic and social costs of higher taxes are well known and have been the focus of policy reforms throughout the OECD over the past two decades. For France (see OECD, 2003, Chapter I) these pressures suggest that in the absence of reform total spending is likely to rise by as much as 8 per cent of GDP (19 per cent if the debt is allowed to accumulate) over the next 50 years, with significant increases beginning in the next decade. Unlike many of its economic partners France has made relatively little progress in preparing the fiscal room to meet these pressures (Table 4). Thus while other OECD countries have reduced the share of public expenditure in GDP by one percentage point since 1990, spending in France actually increased by 3 percentage points. More recently, France has reduced spending by 1.1 per cent of GDP since 1995, but this mainly reflects cyclical factors and pales in comparison with the progress made in other OECD countries. Countries such as Sweden, Finland and Canada have been able to cut spending by as much as 10 per cent of GDP, while other European countries such as Belgium, the United Kingdom, the Netherlands, Norway, Denmark, Italy and Austria have made two to three times as much progress as France.

Figure 4. Slippage in multiyear targets Per cent of GDP
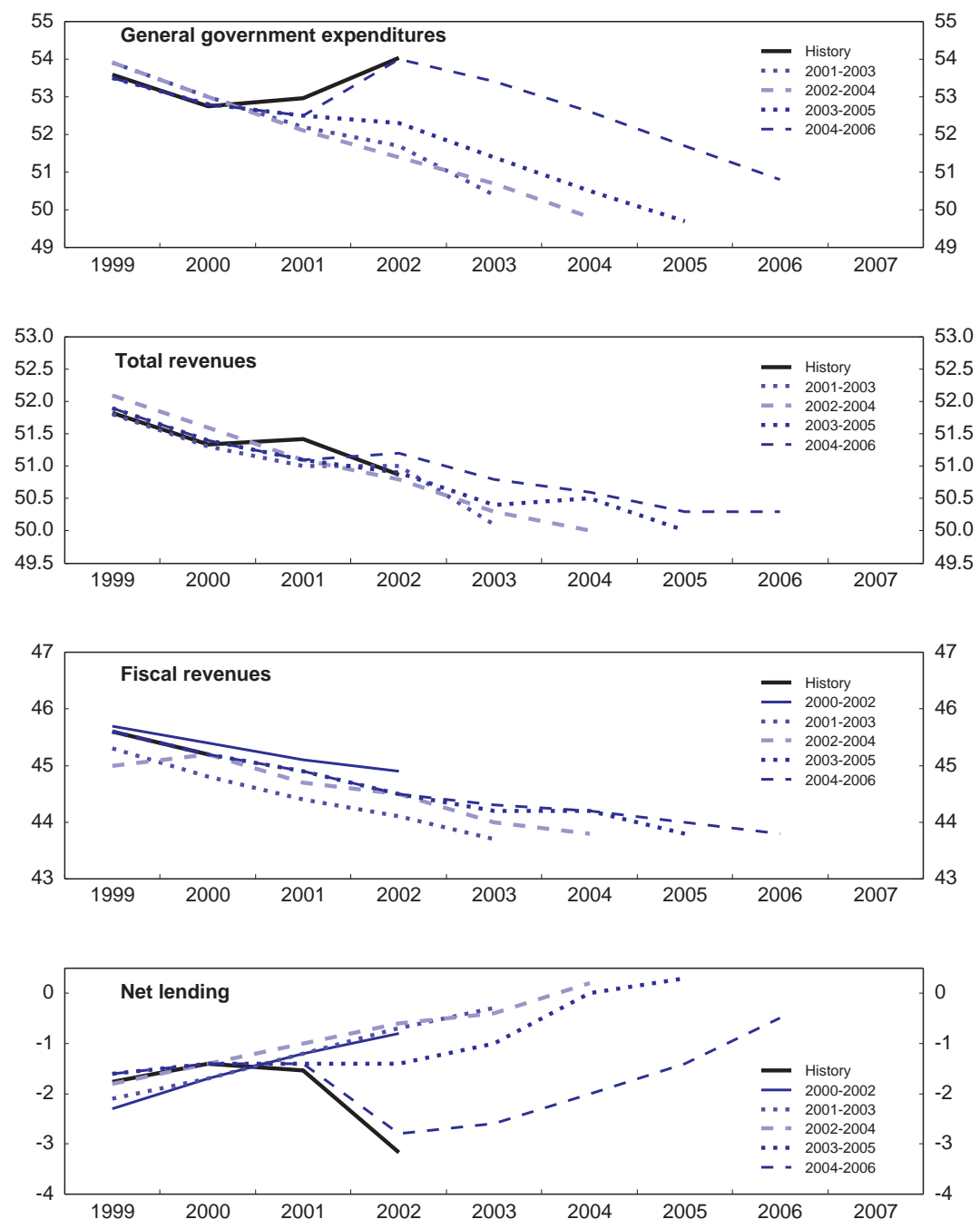

Source: Various issues of Projet de loi de finances; INSEE and OECD. 
27. The repeated failure of the authorities to meet their medium-term spending objectives and the long-term ratcheting up of government expenditure reinforce the need to improve the capacity of decision makers to control public spending. With the exception of 2002, the authorities were able to respect their goals at the level of the State Budget. But constant and significant expenditure overruns in the social security account (mainly healthcare) meant that rather than the Budget balance predicted in the 1999 multiyear plan, the authorities now expect the deficit for 2003 to come in at 3.4 per cent of GDP, a full percentage point higher than the level observed before this process of fiscal consolidation began. ${ }^{9}$ While cyclical and electoral factors appear to have influenced the most recent slippage, its extent and the similarity to previous episodes where expenditures reached new levels during economic downturns are disturbing (see Figure 4).

28. In many respects, the system of managing expenditures in the State Budget is of the highest quality. Stringent controls both ex post and ex ante help ensure that public funds are spent only as authorised, while the central treasury function means that the authorities have a strong sense of fiscal developments, allowing them to employ their significant discretionary powers to counteract any apparent slippage in the State Budget. However, the State Budget represents only 35 per cent of total spending, and even if it cut its activities by 50 per cent, these savings would not be sufficient to compensate for rising pension and health costs. ${ }^{10}$ As a consequence, rigour in the State Budget needs to be accompanied by slower growth in social security expenditures and improved mechanisms for reflecting national spending objectives at the sub-national level. At the level of social security, less comprehensive controls and oversight over mandatory spending, plus the large number of overlapping responsibilities, complicate the task. At the sub-national level, tight budgetary rules limit deficits. Moreover, their track-record in delivering programmes in a cost-efficient manner is perceived to be better than of the central government. However, there are no mechanisms for co-ordinating spending levels at the sub-national level. Thus, as more of public expenditure is transferred to this level, it will become increasingly difficult for central authorities to direct overall general government spending both for short-term fiscal policy reasons and so as to meet longer term strategic objectives. Therefore, in concert with steps to raise the spending authority of sub-national levels of government, it will become increasingly necessary to introduce mechanisms that guarantee that they play a part in the overall effort of expenditure control.

29. The case of the social security regimes is even more complicated because while the State exercises considerable control over the parameters of the various systems and covers their revenue shortfalls, the administration of each (and some cost levers) are in the hands of the social partners. With the possible exception of the UNEDIC, neither the government nor the social partners have the exclusive means to control expenditures (or revenues). This lack of symmetry between responsibilities and authority to act, coupled with the mandatory and politically sensitive nature of these expenditures, is a recurring source of conflict between the government and the social partners -- one which has contributed to the lack of progress in reforms. Indeed, on several occasions, efforts of each to control costs have been frustrated by the other.

30. There is no simple solution to this asymmetry. The reforms outlined below should improve the system's capacity to contain cost pressures. It privileges mechanisms that might improve the ability of the Parliament and the government to manage expenditure, not because they have done or are necessarily likely to do a better job than the social partners, but because, as the elected representatives of the whole population, they bear ultimate responsibility for the public debt and the performance of the economy.

9. The relatively healthy budgetary balance of the social security system does not reflect expenditure restraint but efforts to reinforce its revenues by increasing its share in tax revenues and State transfers.

10. Although a 50 per cent cut in State expenditures represents about 9.5 per cent of GDP, pre-existing state employee pension obligations (which are financed from general revenues) are projected to grow from about 2 per cent of GDP to some 6 per cent of DGP in 2050, reducing considerably the public savings. 
ECO/WKP(2004)32

\section{Exercising better control over the expenditure path}

31. If policy makers are to assert control over public expenditures, they need to be confronted with accurate and comprehensive information about budgetary developments, both in the current year but also for the future. For the moment, the strictly annual nature of the State and social security budgets prevents decision makers from having a clear vision of the longer-term implications of policy decisions. This increases the risk of passing legislation whose in-year costs may not be that large, but which have longterm implications on spending. Indeed, the ratcheting up of public spending over the past thirty years suggests that there has been a marked tendency to increase spending in a permanent manner during cyclical peaks (Figure 5), with the result that during downturns the ratio of public expenditures to GDP has risen.

32. In order to improve the information available to policymakers and to combat tendencies to raise the level of expenditures permanently during revenue-rich periods of the cycle, new spending and revenue measures should systematically include evaluations of their medium-term impacts on the general government budget. In order to ensure consistency, these should be based upon centrally defined macroeconomic assumptions, and the technical assumptions that underlie these evaluations should be submitted to a central agency for review. Currently, such evaluations are done by the Ministry of Finance for large programmes, but not for smaller ones and, even with larger ones, these analyses are not integrated into the budgetary process. Of course, for such a system to be effective it is critical that macroeconomic and revenue assumptions be prudent, which has arguably not been the case in the past. Indeed, the deficit reduction plans of the French authorities in 2001 and 2002 were predicated on the economy growing at 3 per cent, substantially higher than its potential rate of growth and, in the event, much faster than actual growth. A superior solution would be to base medium-term projections on assumptions of GDP growth more in line with the economy's potential. In this respect, the 2.5 per cent growth assumption in 2002 was more realistic, even if substantially higher than most estimates of potential growth, which tend towards 2.1 and 2.2 per cent. ${ }^{11}$ Moreover, the ONDAM would need to be set at a more realistic rate. If healthcare reforms (see below) do not succeed in generating sufficient savings a high but realistic ONDAM will help impress on policy makers the need to generate savings elsewhere. Finally, given that the longer-term sustainability of public expenditures in France has yet to be assured (see OECD, 2003, Chapter I), any revenue windfalls, deriving from better than expected macroeconomic performance or privatisation should be immediately assigned to paying down the debt.

33. While such a setup would help impress upon decision-makers the longer-term fiscal consequences of new policy initiatives, the authorities' capacity to engineer a reallocation of resources and perhaps a reduction in overall spending levels would be enhanced further if the State and Social security budgets were more clearly integrated into a medium-term framework. Significant progress towards integrating multiyear forecasts into the parliamentary debate have been made. In particular, the budget orientation debate, the inclusion of the multiyear plan into the budget documentation and reports on the evolution of tax revenues all go in this direction. However, these projections remain an annex that is presented to parliament as a programme of the executive. In order to consolidate recent progress and so as to increase the visibility of the medium-term consequences of various decisions, these projections should be integrated into the budgetary procedure, discussed, debated and approved by parliament. Moreover, because information on individual Budget and social security programmes or "missions" is not included, it is not possible to isolate the influence of different spending initiatives in out years, nor the basis for the fiscal consolidation that is asserted (a factor, which along with unrealistic assumptions helps explain the failure of these goals to be achieved).

11. The authorities justified this difference by the presumption that there existed a significant negative output gap that could be absorbed. While OECD estimates of potential growth are broadly in line with those of the authorities (see OECD, 2003, Chapter II), they suggest that the gap in 2002 was significantly smaller than the one outlined in the PLF. 
Figure 5. Asymmetric response of expenditures to the economic cycle Per cent of GDP

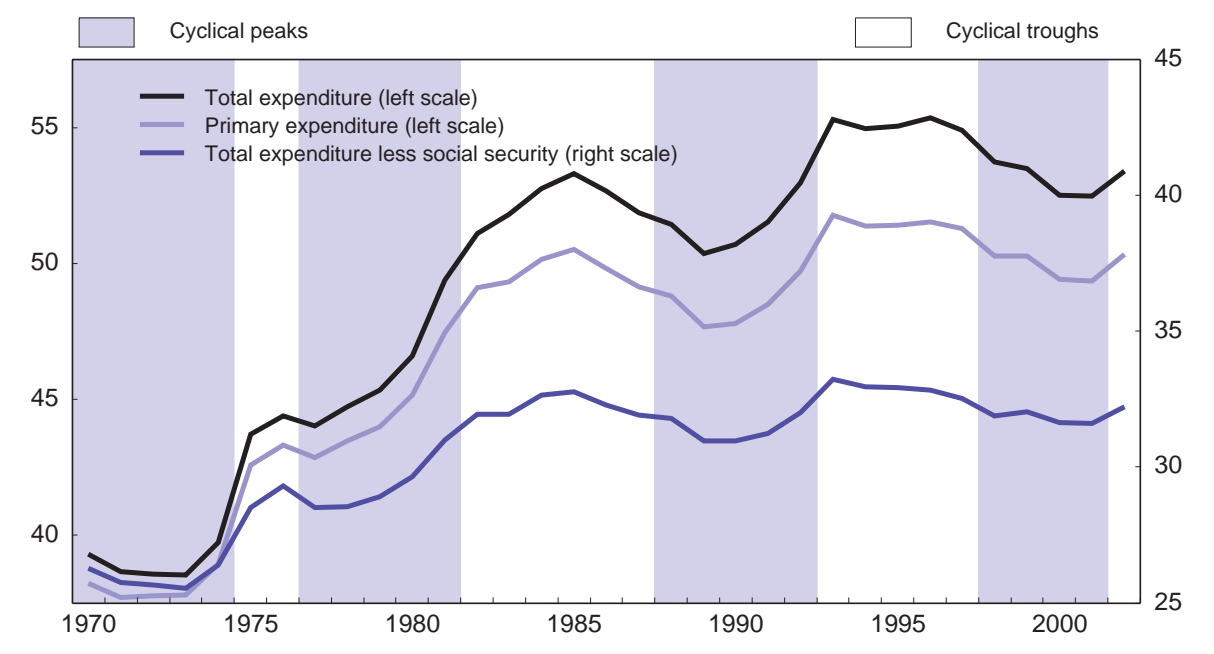

Source: INSEE and OECD.

34. Given the major changes in budget procedure already implied by the introduction of the LOLF (see below), it is probably inopportune to move towards a true medium-term expenditure framework at this time. One solution might involve maintaining the separation of the State Budget and the Social Security Funds and their single year focus, but presenting and anchoring them within a more detailed and rigorous medium-term projection. This enhanced medium-term projection could serve as an umbrella for the two single-year budgets but also extend them several years into the future, based on common macro assumptions and unchanged policies (or on explicit indications of where savings would be generated to meet medium-term goals).

35. As compared with current practice, this would imply including more detail into the multiyear plan concerning spending missions and the activities of the social security funds. The outyear budgetary projection, after adjustment for changes in macroeconomic developments, could then be used as the basis for the following year's budgets. This would help reinforce the virtuous circle created by the existing examination of the past year's outturn, by increasing its scope to the whole of the general government and by linking it more directly to the discussions of the next year's budget.

36. Bringing forward the preparation of local government budgets would also help. In so far as their activities represent 19 per cent of GDP, the ability of central-government decision makers to plot both short-term and medium-term fiscal policy at the general government level would benefit from more timely contributions from the local level. Moreover, given that revenue estimates are decided well in advance of the actual voting of the Budget, there is no apparent technical impediment for local governments to provide provisional budgets in time for the parliamentary debate and to finalising them much more quickly after passage of the State Budget. To help ensure that expenditure savings at the central level are not undone at the subnational level, the authorities might wish to introduce mechanisms that ensure subnational 
governments take responsibility for the macroeconomic consequences of their actions. Here, departmental and regional spending norms analogous to those at the national level or other mechanisms that would guarantee that subnational levels play a part in overall efforts to control spending might be envisioned.

37. Such solutions have several advantages:

- They would not require any fundamental legal changes;

- They would further reinforce the notion of the general government and the inter-relationships between social security and other forms of public expenditure;

- Unchanged policy projections would make explicit the savings or revenue shortfalls that would be required to meet medium-term spending objectives;

- The use of the previous year's projection as a starting point for the following years' budgets, would enhance transparency;

- Prudent assumptions for future developments would help prevent windfall revenue increases from being transformed into permanent increases in spending commitments. ${ }^{12}$

\section{Controlling mandatory expenditures}

38. Mandatory expenditures (health, unemployment insurance, pensions and social assistance) represent more than 40 per cent of general government spending and are its fastest growing component. As such, the ability of the authorities to control these expenditures (principally social security spending) will determine crucially their success in containing overall cost pressures. The increased prominence of social spending in overall public expenditure, ${ }^{13}$ which has been observed in virtually all OECD countries, reflects three main factors: a substantial widening of the roles undertaken by the general government; ${ }^{14}$ the mechanical impact of ageing on health, pension and family assistance expenditures; and technological and demand-side changes associated with rising incomes, which have weighed heavily on the rate of increase of healthcare costs.

Pension reform

39. OECD simulations (see OECD, 2003, Chapter I) illustrate the substantial additional fiscal pressures that the ageing of French society is likely to entail and the risks they pose to fiscal equilibrium. The current pension reform initiative is a first step towards meeting these pressures. However, even at their most ambitious, current proposals only seek to address somewhat more than one-third of the system's underfunding. In particular, the remainder of the financing as concerns the private sector is achieved at a constant overall tax burden by assuming substantial reductions in unemployment insurance expenditures.

12. For instance, rather than reacting counter-cyclically, labour market policy spending appears to have increased structurally over the past decade (IMF, 2002). In particular, expenditures for subsidised statesector employment did not diminish towards the end of the last decade, notwithstanding reports of widespread hiring difficulties in the private sector and indications that these programmes were having limited impact on the long-term employability of participants.

13. The share of social security spending in GDP has risen by 50 per cent since 1970, from 12 to 18 per cent.

14. Specific examples in recent years include the introduction of a universal healthcare coverage, a programme of in home assistance for the aged and in large measure the cuts to social security contributions to offset the costs of firms from moving to the 35 hour work. Indeed, it should leave open the possibility for a reversal in trends. 
Thus, whatever shape this reform eventually takes it will need to be extended. While decisions as to the precise nature of any final reform are the responsibility of the French authorities, international experience and the nature of the current system suggest some courses of action over others that would generate savings while respecting social and equity concerns.

- Raising social contributions yet further seems a particularly unattractive option, given the already high tax burden and the considerable economic inefficiencies that would likely be generated by the 10 percentage point hike estimated necessary by the government's Retirement orientation council (Conseil d'orientation des retraites, $\mathrm{COR}$ ).

- There is likely scope for reducing replacement rates without endangering the income adequacy of the elderly. Indeed, the average revenue of a retired person in France is higher than the rest of the population (see Box 4).

- Increasing contribution periods, as proposed by the authorities, in line with improving longevity also seem reasonable. At a minimum these should be increased in an actuarially neutral manner, although given the overall disequilibrium of the system and the substantial improvements in life expectancies already achieved a non-neutral increase might also be merited.

- Augmenting individuals' freedom to decide when to retire by stopping the subsidisation of early retirement and by permitting early withdrawal with actuarially reduced benefits would be helpful, especially if combined with the ability to continue working while increasing pension rights or to work and simultaneously draw a pension (see below).

The system should be made more equitable by:

- treating pensions and earnings in a more actuarially neutral manner (Guegano, 2000 calculates that 9 per cent per year (de) increment to a pension per year of contributions would be actuarially neutral at age 62$) ;{ }^{15}$

- eliminating subsidised early-retirement programmes;

- reducing the inequalities in the treatment of public-sector and private sector workers.

\section{Box 4. Incomes of the elderly}

In France, the disposable income of individuals over 65 is 90 per cent of those of working-age (Förster and Pellizari, 2000), making French retirees the fourth richest in the OECD. Moreover, if an imputation is made for owner-occupied housing, they actually have higher incomes than working-age people (see Table 5). While the overall pension scheme contributes significantly to this result, it reflects to a large extent the substantial wealth accumulated in non-pension private-sector savings schemes such as those operated by the insurance sector. ${ }^{1}$ These resemble defined-contribution private-sector pension schemes seen in other OECD countries and benefit from similarly favourable tax treatment. In recent years, there has also been increased take up in two new voluntary saving schemes (plans d'épargne entreprise - PEE and plans partenariaux d'épargne salariale volontaire - PPES). These receive very favourable tax treatment; contributions are exempt from both income tax and social charges, while benefits are only subject to a 10 per cent tax rate.

Finally, while 10 per cent of the elderly have less than half the disposable income of an average person, minimum pensions and additional dependency allowances have virtually eliminated absolute poverty among the elderly.

1. All told, individuals over 50 hold about three quarters of these assets, which combined with other financial assets are worth 3.7 times household disposable income (a higher ratio than in Spain, Germany and Italy).

15. Based on the assumption of a person having contributed 40 years, aged 62 years of age and with a real rate of return of 3 per cent. 
40. As concerns this last point, the differences between public- and private-sector regimes are substantial and exist along virtually every dimension of the two systems, working almost universally in the favour of public servants (Box 5). In part, the existing differences reflect steps taken in 1993 to improve the sustainability of the private-sector system and the failure to implement similar reforms in 1995 for the public-sector regimes. Overall the favourable treatment of the public sector regimes is reflected in the fact that although their adherents represent only 25 per cent of workers, the projected deficit of their regimes is expected to be about the same size as that of the private-sector regimes, implying that the per capita contingent liability of the public sector scheme is three times that of the private sector one (Table 6). Indeed, the present value of current government liabilities to civil servants, at between 600 billion euros to 800 billion euros, is more than the outstanding gross public debt (Marini, 2002). Harmonising the two systems, by bringing the public-sector scheme into line with the private sector could be expected to eliminate $1 / 3$ of the total expected shortfall.

\section{Box 5. Main difference between public- and private-sector pension schemes}

1. Contribution periods: In general public servants must work only 37.5 years before qualifying for a full pension, in contrast to 40 years in the private sector. Moreover, many public servants and employees of State-owned enterprises benefit from special regimes which allow them to leave at 55 or even 50 years of age. Mothers of three or more children can retire after only 15 years of service, with no reduction in benefits to reflect the long period they will be collected. In contrast, private-sector workers must work until 60 and do not qualify for a full pension until they have worked 40 years.

2. Contribution rate: Public sector employees contribute only 7.85 versus 10.3 per cent in the private sector.

3. Calculation of benefit: Private-sector workers benefits are based on the average of 25 years of inflation (not wage) adjusted salary. Public-sector workers pensions are based on the salary excluding bonuses, which are not subject to charges) earned in their last 6 months of work. Moreover a significant percentage of public servants receive substantial promotions just prior to their retirement - effectively substantially increasing their replacement rate.

4. Replacement rate: While the pension an individual receives does depend on his or her contributions, both system are highly redistributive. Thus, in the private sector system overall replacement rates in the private sector vary from 54 per cent for managers that received many promotions to 87 per cent for blue collar workers. In the public sector they vary less, ranging from 60 to 78 per cent depending on how much of an individual's income comes from bonuses and excluding the effect of end career promotions. Moreover, the degree of inequality is projected to increase as private-sector replacement rates are projected to fall by between 9 and 17 percentage points by 2040 , reflecting the impact of the 1993 reform of the private-sector scheme. ${ }^{1}$

5. Indexation: civil servants' pensions are indexed to public-sector wages, whereas those fo the private-sector are adjusted according to price inflation.

1. In addition to increasing working requirements from $371 / 2$ to 40 years, the reference period for determining benefit rights was extended from 10 to 25 years and inflation replaced wage growth as the mechanism for indexing earlier salaries in the calculation.

41. The pension reform bill that was presented to Parliament in June 2003 proposes a number of changes aimed at reducing some of these inequalities. In particular, it proposes raising the public-sector normal-contribution period to 40 years (see OECD, 2003, Chapter I). These are steps in the right direction, but will only begin to deal with the discrepancies between the two systems. In particular, they leave untouched the various special regimes allowing for very early retirement within the public-sector regime per se and those operated by state-owned enterprises. Moreover, the reform does not deal with the abusive practice of giving public servants substantial promotions just before their retirement, nor does it deal with the fundamental inequity that replacement rates in private-sector pensions, which are already lower than 
those in the public sector, will be falling by between 9 and 17 percentage points over the next several decades (as the impact of the 1993 reform comes on line), while those in the public-sector will not if the individuals concerned continue working so as to receive a full pension.

Table 6. Official estimates of pension fund balances

\begin{tabular}{|c|c|c|c|c|c|c|c|c|}
\hline \multirow{4}{*}{$x^{2}$} & \multirow{3}{*}{$\begin{array}{c}\begin{array}{c}\text { Number } \\
\text { of } \\
\text { workers }\end{array} \\
\text { Million } \\
1998\end{array}$} & \multicolumn{2}{|c|}{$\begin{array}{c}\text { Pension } \\
\text { expenditure }\end{array}$} & \multicolumn{5}{|c|}{ Pension fund balances ${ }^{1}$} \\
\hline & & $€$ billion & $\%$ GDP & \multicolumn{5}{|c|}{$\%$ GDP } \\
\hline & & \multicolumn{2}{|c|}{2000} & 2000 & 2005 & 2010 & 2020 & 2040 \\
\hline & \multicolumn{8}{|c|}{ Base case } \\
\hline Private-sector employees & 14.2 & 95.5 & 6.7 & 0.4 & 0.7 & 0.5 & -0.6 & -1.9 \\
\hline Government employees $^{2}$ & 4.4 & 37.5 & 2.6 & 0.2 & -0.1 & -0.5 & -1.3 & -2.0 \\
\hline Public enterprise employees ${ }^{3}$ & 0.4 & 7.7 & 0.5 & -0.2 & -0.2 & -0.2 & -0.2 & -0.2 \\
\hline Self-employed $^{4}$ & 0.9 & 2.6 & 0.2 & 0.0 & 0.0 & 0.0 & 0.0 & -0.1 \\
\hline Farmers $^{5}$ & 1.4 & 12.0 & 0.8 & -0.6 & -0.5 & -0.9 & -1.3 & -2.0 \\
\hline Others & 1.8 & 9.5 & 0.7 & -0.4 & -0.6 & -1.0 & -1.8 & -2.5 \\
\hline All covered workers & 23.7 & 164.8 & 11.6 & -0.6 & -0.5 & -1.0 & -2.8 & -4.7 \\
\hline \multicolumn{9}{|l|}{ Base case assumptions } \\
\hline Economic growth ${ }^{6}$ & & & & & 3.0 & 3.0 & 1.5 & 1.4 \\
\hline Unemployment rate & & & & 9.7 & 7.5 & 4.5 & 4.5 & 4.5 \\
\hline \multicolumn{9}{|l|}{ Alternative scenario $^{7}$} \\
\hline All covered workers & & & & -0.6 & -0.9 & -1.9 & -3.9 & -5.9 \\
\hline \multicolumn{9}{|l|}{ Alternative assumptions } \\
\hline Unemployment rate & & & & 9.7 & 9.0 & 9.0 & 9.0 & 9.0 \\
\hline
\end{tabular}

1. Contributions minus pension spending. A positive value shows a surplus. As regards civil servants, employers contributions reflect actual receipts for local government employees. For central government employees whose pensions are paid from the budget, the fictive rate of employers contribution that balances contributions and pensions in 2000 is kept constant onwards to run the simulations reported here.

2. Including government employees on private law contracts.

3. Namely SNCF, EDF, GDF and RATP. The method of the fictive rate (see above) is also used here for determining employers contributions.

4. Excluding self-employed farmers.

5. Including farm employees.

6. OECD estimate of potential economic growth to 2005 is 2 per cent.

7. The alternative scenario has been extrapolated from the sensitivity analyses given in COR (2001).

8. OECD estimate of the structural unemployment rate in 2005 is 9 per cent.

Source: $\quad$ OECD computations on the basis of COR (2001) for financial projections. Charpin (1999) for number of employees apart from the item "others" which is a Secretariat estimate.

Healthcare

42. Given the demand-driven nature of costs in the Healthcare system, slowing the speed at which expenditures rise will be more complicated, as indeed it is in all OECD countries (Docteur and Oxley, 2003). Several recent and planned initiatives should serve to slow the pace of health insurance costs. In this regard, recent reforms to increase the use of generic drugs and to ease or lower the rate of subsidisation of drugs of questionable medical efficiency are positive steps, which can, by lowering the level of spending in a given year, slow the overall progression of costs. Similarly, proposals to reduce the extent of the coverage of the compulsory healthcare system but simultaneously extending universal coverage to more 
individuals, while augmenting the share covered by voluntary complementary insurance schemes and allowing them to determine reimbursement rates for non-essential medical services, would also help if implemented (Chadelat, 2003). Such a reform would tend to raise awareness among healthcare demanders of the costs of various options -- and in so doing reduce the rate of growth of healthcare costs -- while at the same time ensuring that all continue to have access to a high level of care. By the same token, it will be necessary to make the ONDAM more binding. The government would also like to produce a report on the medicalisation of the ONDAM in order to be able to forecast its evolution on medical grounds. Such an initiative, if put in place, would have the further advantage of emphasising objectives as opposed to inputs when planning for healthcare. Additional measures that might be considered, which could improve the authorities leverage over the rate of growth of expenditures were outlined in the special chapter on the health care system included in the 2000 Economic Survey. These included:

- The introduction of diagnosis-related payments for hospital-based care. This has entered on experimented phase and once generalised it should increase incentives to reduce administrative, medical and pharmaceutical costs. ${ }^{16}$

- $\quad$ Expand the role of the regional hospital agencies (Agences régionales d'hospitalisation, ARH) so that they can operate as care purchasers, which would give them incentives to limit supply-side based increases in costs.

- Work with private insurers to devise a mechanism of complementary health insurance that covers additional risks, but which does not eliminate the dissuasive effect of co-payments.

- Extend the system of referring doctors so as to better control access to some kinds of specialists, where considerable sums are spent subsidising medically dubious activities. One solution might be to reimburse visits to specialists that are made without referral at the same rates as visits to general practitioners.

- Introduce a rolling cap on ambulatory-care medical services, such that if the ONDAM is violated in a given year, the remuneration per service in the following year is reduced by the amount of the previous year's overshoot.

43. While introduction of such changes would not eliminate the tendency for healthcare spending to rise, they would increase the levers available to the authorities to exercise pressure on both demanders and suppliers as well as increase each group's private incentives to limit reimbursable spending. This, plus the continued pursuit of changes that offer one-off reductions in health care costs appear to offer the best hope for controlling costs in this area.

\section{Managing fiscal consolidation in the social security system}

44. Effectively applied, the institutional reforms to the budget process outlined above (joint presentation of the social security and State budgets in a medium-term context) will help by forcing decision makers to confront the medium and long-term consequences of adding tasks to the social security system without provisioning them and make it more difficult to mistake cyclical improvements in revenues for permanent ones. In this regard, further integrating the discussion of the social security budget with that of the State should help extend to these programmes the kind of scrutiny and arbitrages currently undergone by programmes covered by the State Budget. Moreover, by treating the Social security and State Budgets together, it should increase the visibility of opportunities for reallocating resources between programmes. Finally, it should help the authorities avoid increasing the unfunded tasks assigned to (or taken on by) the social security system, ideally by explicitly identifying savings in non-priority areas to finance additional tasks. For instance, a medium-term analysis of family assistance expenditure based on

16. Currently hospital-based care is budgeted, giving individual hospitals little financial interest in reducing costs. 
unchanged policies should, given demographic developments, reveal falling expenditures and therefore the possibility of reallocating resources to other priority areas where expenditures are growing (such as healthcare or pensions).

45. To be able to effectuate such reallocations, the government will need to rethink the financing of the social security system. Reliance on earmarked funds for the financing of the various social security regimes and the mixed administration of these programmes seriously constrains opportunities for reallocations and effectively eliminates 40 per cent of public expenditure from any fiscal consolidation programme, significantly increasing the pressure on other programme areas. Dedicating resources to a particular policy problem demonstrates the political importance attached to an issue and can, in certain cases, serve as a hard budget constraint. However, it also unnecessarily constrains policy makers' ability to respond to changing priorities and conditions and can result in mission creep and budgetary inertia when the constraint is not binding. ${ }^{17}$ For example, the strict budget constraint imposed by earmarking has, in conjunction with the considerable administrative autonomy enjoyed by the administrators of the UNEDIC, meant that this unemployment insurance system has more or less succeeded in maintaining budgetary equilibrium. In contrast, demographic developments have tended to reduce demands on the family assistance system, which has responded by seeking new missions for itself in order to make use of the resources that its fixed share in social security charges generate. Finally, in the case of healthcare and pensions, popular expectations for and the costs of the systems have evolved much faster than the funds' ability to pay. As a consequence, the budget constraint could not be respected, resulting in the build up of a substantial debt in the case of the healthcare system and a huge unfunded contingent liability in the pension scheme. Because of the public policy nature of these activities, responsibility for finding a solution to these problems has tended to fall to the government.

46. In order to redress the asymmetries in the governance of the social security system, the government needs to take a more active and responsible role. The compulsory nature of the funds, the contributions they impose and the substantial redistributive nature of these contributions gives the State the obligation to oversee their activities (indeed, this is implicit in the requirement that the State decree the contribution rates proposed by the funds). Moreover, given the large sums required to finance these activities and the impact that associated charges and taxes have on the functioning of the economy, the State would appear to have a legitimate right (if not obligation) to dictate (or at least negotiate) the level of expenditure and contribution rates for the regimes. The introduction of the Loi de Finances de la Sécurité Sociale, by placing these issues before Parliament, constituted an assertion of the Parliament's legitimate interest in these areas of public expenditure. However, if the authorities are serious in their efforts to control overall expenditure levels, they will inevitably need to assert this right more directly. In exchange, however, they may need to take a step back from the management of the expenditures of the social security systems themselves, giving the social partners the responsibility and the authority to meet the budget constraint imposed by the State.

47. One step worth considering would be to replace the funding of the social security by earmarked taxes with direct financing from the State Budget. Such a move would have the considerable advantage of facilitating budgetary reallocations and clarifying the true costs of these programmes. Moreover, it would obviate the need for the complicated cross-subsidisations and extra-budgetary funds that currently characterise the system. The proposal to transfer contributions from the unemployment insurance scheme to the pension scheme as society ages works in this direction, although it retains the earmarking of funds. While stop-gap measures have allowed the system to be maintained, they obscure the financing of the social security system and mask the true costs of these services in the public eye. Moreover, such transfers of "dedicated" resources are frequently perceived as an illegitimate misappropriation of funds destined for one objective towards an unrelated one (from families to pensioners on the one hand and from the medical

17. Indeed, it is largely because the rigidities implicit in earmarking that the constitution explicitly prohibits earmarking of funds within the Budget of the State. 
and family systems to labour market policy in the other). Finally, the combination of the rapid increase in these expenditures and their financing through social contributions resulted in an overall tax wedge that was particularly penalising of labour. To a considerable extent, the distortions that this created have been eliminated by various reductions in the social charges imposed on low-skilled workers (see OECD, 2003, Chapter II), but only by transferring these charges to the State Budget and further undermining the contribution-based characteristics of the social security systems.

48. A less radical reform in the same direction would see the authorities make greater use of transfers from general revenues in subsidising the activities of the various funds. Transforming the State-based financial support that are currently generated in the form of earmarked excise taxes $(90$ billion euros, or 6 per cent of GDP) into a direct transfer would allow the authorities to apply these funds according to their priorities, and could be used as a mechanism to tighten the budget constraint of the funds. Indeed, such funds could be managed in a countercyclical way to help smooth funds revenues and prevent the observed tendency for parameters to be adjusted in a procyclical manner. ${ }^{18}$ Moreover, the authorities might wish to reconsider the contributions they make to funds to extend coverage for certain classes of individual. For example, the State currently pays the social security contributions of unemployed workers, effectively subsidising the UNEDIC's de facto early retirement scheme. Making these funds conditional on a reform to this programme would not only improve the coherence of government policy but also serve to reduce the spending of both the UNEDIC and the State Budget. Finally, the various special funds that serve only to move money from one arm of the government to another, albeit social security funds, should be abolished and replaced by direct transfers.

49. The authorities (and the social partners) also need to take a close look at opportunities to generate administrative savings in the social security system. The resort to 38 separate funds and associated administrations to deliver 3 public services (health, old-age pensions and social assistance) results in significant inefficiencies (Figure 6) and horizontal inequity. ${ }^{19}$ Moreover it would appear that a consolidation of the administration of the funds could result in substantial savings. ${ }^{20}$ Indeed, it is difficult to see the utility of the hundreds of independent local administrations, especially given that modern advances in informatics technology should enable a more centralised and economic treatment of dossiers.

18. The expenditures of the unemployment insurance system, which should normally be strongly countercyclical, have been pro-cyclical on a structurally adjusted basis. Rather than paying down its debt or building up reserves during up-turns, the UNEDIC has reacted, on more than one occasion, by reducing contributions and increasing benefits -- only to reverse itself during the downturn.

19. This is perhaps most obvious in the case of the pension schemes, where, barring reform, the tax payer is being asked to pay the deficits of the most generous special and complementary regimes.

20. Administrative and management costs are estimated to represent 10 per cent of non-hospital medical expenditures (Commission de comptes de la Securité Sociale, 2000). This falls to 6 per cent if hospital grants are included in the denominator but State contributions to hospital administration excluded. 
Figure 6. Range of activity of social security schemes ${ }^{1}$

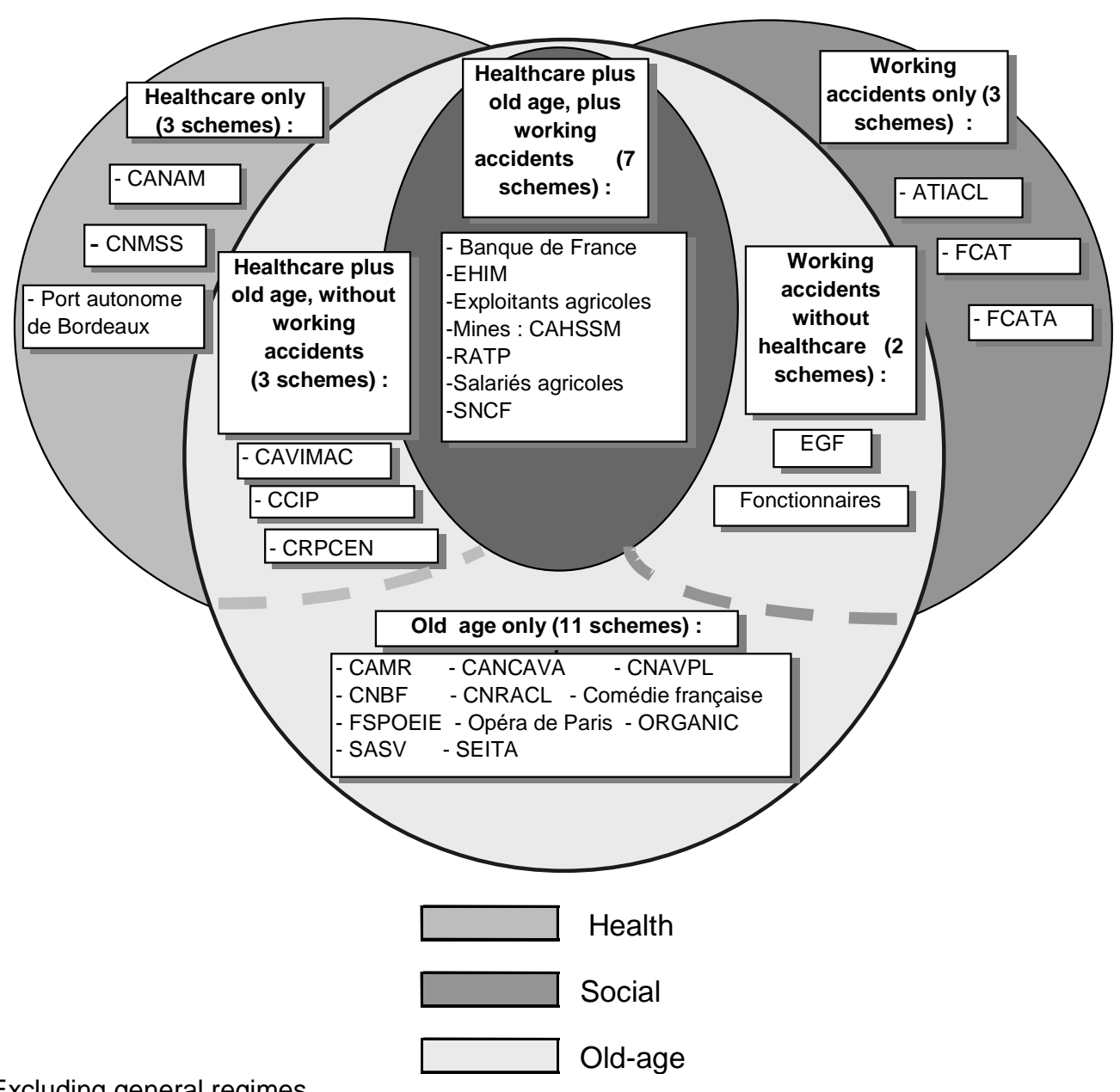

1. Excluding general regimes.

Source: Direction de la Sécurité sociale.

\section{Improving the oversight and efficiency of public expenditure}

\section{The new State Budget framework law}

50. The new Budgetary framework law (Loi organique relative aux lois de finances, LOLF) represents an important step towards enhancing the quality and efficiency of public spending programmes. This law, which defines the legal framework for the annual Budget Laws, was passed in 2001 and is to be phased in gradually over the 2002-2006 period. It substantially enhances the oversight and investigative powers of the Parliament and gives the State Budget process much more of a results and output-based orientation. Moreover, by requiring the government to present to Parliament a closing account of the previous year's Budget (Loi de règlement) before it considers the proposals for the following year, the authorities hope that the LOLF will introduce an element of multiyear planning in what remains a strictly annual budgetary process. Finally, concomitant with the move to an output-based orientation it delegates much of the responsibility for the allocation of budgetary envelopes to public-sector managers, while making them responsible for reporting on and delivering results.

51. As part of the phase-in of the LOLF, the current 848 budget chapters detailing the inputs allocated to each Ministry will be replaced by some twenty-odd missions, grouping together various 
programmes by objectives. The government retains the sole authority for defining budgetary missions and their objectives as well as the funds to be allocated to each. Although the parliament can change allocations within missions it cannot affect them between missions and cannot change the total level of expenditure. Given the resource allocations made available to them by the parliament and the government, managers are free to allocate funds across inputs. ${ }^{21}$ Coupled with this delegated authority will be an enhanced responsibility, with managers to be responsible for determining and reporting indicators of the extent to which parliamentary objectives are attained. Parliament, in turn will be responsible for evaluating these results and revising its policies and law in consequence.

52. While Parliament does not have the authority to amend total budgetary allocations or those for given missions, its oversight role does give it a platform to make such recommendations, which the government may or may not decide to incorporate. This extends parliamentary influence. Nevertheless, there is scope for extending it further. In particular, while initial budgetary allocations across missions should remain the purview of the government, the capacity of the authorities to define and pursue priority objectives could only be enhanced if Parliament were allowed to revise mission allocations (as long as the original expenditure cap is not exceeded).

53. The introduction of the LOLF represents a major step forward and an important opportunity to raise the effectiveness of public policy and the quality of public expenditure. However, experience from other countries suggests that its implementation will not be straightforward, in part because of the substantial changes required in terms of both administrative and political culture. Even in countries that have instituted such a system for many years, results have been mixed. While a real culture of evaluation has developed in some countries and in some ministries, in others implementation has been pro forma and the process is considered an additional and not very useful administrative burden. Thus, notwithstanding the four years allocated for the phase-in of the LOLF, its success is not guaranteed and much will depend on the political and administrative will to see it through, to allow for experimentation (and failure) and to nurture a spirit of evaluation and responsibility among both public servants and elected representatives.

54. To facilitate the transformation in administration culture, it will be essential for spending Ministries and departments to participate actively in the preparation of mission objectives and evaluation strategies. To be effective, such objectives must not only be measurable, relevant and attainable, they must also be seen as legitimate by those that are called upon to achieve them. Thus, while development of these targets should be overseen by a central agency (so as to ensure the diffusion of best practices in terms of methodology, design and publication of results), care must be exercised to ensure that ownership of the targets remains with those who will be responsible for their execution. In this respect, Ministries are in the process of creating objectives for the 2004 Budget exercise and special Ministry-specific groups, supervised by the Department of the Budget, have been put together to follow the process offering advice and encouraging laggards. Moreover, pilot projects have been run both at the departmental level and within the Ministries in an effort both to give an example but also to determine in advance what does and does not work.

55. In order for new public-expenditure management techniques to improve the quality and costeffectiveness of programmes, the policy evaluation process needs to be reinforced. Evaluations need to be structured with an eye to improving programmes, so that specific proposals can be put forward to policy makers on how programmes can be made more effective and ultimately so that parliament can be advised as to how appropriations could be amended, cancelled, or distributed over the medium term. Without this, the evaluation process, and Parliament's role, risks becoming formulistic rather than part of a genuine

21. The degree to which such responsibility will be delegated in practice remains to be seen. Both the political and social sensitivity of staffing decisions, may seriously constrain managerial freedom in this regard, while ceilings on expenditure appropriations will limit the fungeability of resources. 
process geared towards continually improving the quality of public spending. Too often programme evaluations fail to adequately control for selection bias and other statistical phenomena. To assist in this process, new policies should be designed in such a way as to facilitate their subsequent evaluation in a statistically conducive manner. While the LOLF gives Parliament virtually unlimited evaluation powers ${ }^{22}$ over almost all public finance issues (including public entities, state enterprises, the local authorities and the social security sector), ad hoc parliamentary investigations cannot substitute for ones conducted by those knowledgeable about and responsible for programme results. Parliamentary studies might most usefully be used as a "corrective tool" in cases where specific Ministerial evaluations are judged to be inadequate, and to mandate specific analyses into new policy areas or to analyse longer-term questions (i.e. pensions or healthcare). In this respect, the synergies between public service evaluations and active parliamentary oversight would be enhanced if the discussions of the Loi de règlement were better integrated with those of the current year's budget and if the administration was required to make intermediate reports on new programmes in the context of the Budget debate.

56. More generally, the resources allocated to evaluation will have to be increased. Already the Cour des Comptes has indicated that the implementation of the LOLF places substantial new and different demands upon its resources. To a large extent meeting these new demands should be achieved by reallocating posts and expenditures within existing budgets, something made easier by the new budgetary rules. For ministries the new emphasis on evaluation will require new staff with different skills. Fortunately, the imminent retirement of a large proportion of public servants should allow for new hiring even as overall staff levels are reduced. Meanwhile, the introduction of a new data system (mission oriented ACCORD ${ }^{23}$ ) should help facilitate the flow of information about indicators, costs and objectives between the Ministry of Finance, the Cour des Comptes and Parliament.

57. Although not a specific part of the LOLF, the authorities should consider making much greater use of techniques such as sunset clauses that require specific-task spending programmes to be abandoned after a set period of time (typically several years), unless parliament renews their mandate. Such simple measures, which can be introduced retroactively, help combat programme and spending inertia. While such clauses have been criticised as ineffective in some cases, they have been effective in other jurisdictions. Using them to force a regular review of tax expenditures might be useful as such programmes, which involve billions of euros, tend to fall out to the public eye because of their passive nature.

58. The authorities might also wish to re-examine the process by which budgetary expenditures are authorised. The authorisation and audit process, involving three ex ante verifications, is relatively heavy and seems in many respects contrary to the spirit of delegation of authority and responsibility incorporated into the LOLF. Perhaps a system involving a single Ministerial ex ante verification and a reinforced ex post audit system would be just as effective and less expensive to administer.

59. The LOLF only applies to the State Budget. As a result, the remaining 50 per cent of consolidated central government expenditure continues to be budgeted on the basis of inputs. Nevertheless, progress has been made in establishing political oversight of social security expenditures. As noted, since 1996, spending at this level has been exposed to parliamentary scrutiny in the context of an annual Budget Bill for Social Security, the PLFSS, which allows parliamentarians to discuss social security funding at the

22. To date these powers have not been exercised, perhaps reflecting the early stages of the transition.

23. The system is being brought into play in two phases. Overall, it seeks to equip the central administration with a common expenditure management and accounting software application for the stockage and retrieval of indicators, accounting information both at the macro- and micro-budgetary levels. Already eight ministries have been linked to ACCORD I and the remaining three large ministries (Agriculture, Foreign Affairs and Defence) are scheduled for a link by the end of 2003. During 2005 and 2006, ACCORD II will be launched to encompass other minor central services and the local administrations. 
same time as the State Budget. Moreover, an element of output-oriented budgeting has also been introduced into the State's budgetary relations with the social security agencies. Increasingly, the State is passing explicit contracts with the regimes that detail both their objectives and responsibilities (Conventions d'objectifs et de gestion, COG). These could perhaps be improved by requiring a more regular reporting of the impacts of programmes and incorporating a discussion of these into the debate on the PLFSS held each year in parliament. Indeed, a thorough and regular confrontation between the objectives of these programmes spending and their results would help ensure that their goals are achieved at least cost. Moreover, it might well lead to a clearer societal definition of what those objectives are and in this way help to contribute to a constructive reform dialogue.

\section{Raising efficiency at the sub-national level}

60. Existing financial rules concerning sub-national governments strike a good balance between national and local interests by ensuring fiscal sustainability while granting substantial autonomy to local governments as concerns the content of expenditure. Balanced budget requirements and the strict pro rata release of funds to local authorities help guarantee the smooth execution and monitoring of local level public expenditures by the central government and prevent the emergence of major fiscal imbalances. While these rigid cash-flow rules may prevent sub-national governments' from organising their capital expenditures in an optimal manner, they have the advantage of granting local governments budgetary predictability and the liberty to manage money in accordance with local needs.

61. Ongoing efforts to rationalise and better identify the roles of different governmental actors working at the local level should be pursued, especially given the large and rising share of general government services delivered by these levels of government. The authorities' proposed decentralisation initiative seeks to do just that (Box 6). Currently, overlapping responsibilities and various co-financing mechanisms have weakened service providers' incentives to reduce costs. Under the planned reform both financial and administrative responsibilities will be more closely aligned with the natural geographic hierarchy of existing government levels. Thus, regions are to be made responsible for defining broad strategies, departments for delivery and coordination of most local services and infrastructures, while municipalities are to continue being the primary deliverer of such services.

62. This is an important initiative, which if implemented (certain aspects of the reform have recently been put into doubt and its implementation delayed) could generate substantial efficiency gains. In particular, the transfer of both a fixed budget envelope and responsibility for the regional administration of hospitals could help rationalise the distribution of small hospitals and clinics, which until now has been slowed by the conflicting interests of their owner-managers (local municipalities) and the State, which was responsible for financing them. Similarly, transfer to the departmental level of financial and administrative responsibility for both active labour market policies and the main cash social benefit (Revenu minimum d'insertion, RMI) should help sharpen incentives to actively help beneficiaries to find work (for a discussion of the further proposal to transform the RMI into a more active instrument, see OECD, 2003, Chapter II). 


\section{Box 6. Decentralisation ${ }^{1}$}

The government hopes to put in place a major decentralisation reform and has already amended the constitution, with an eye to creating a framework for subsequent changes. The reform seeks to clarify the roles of various levels of government in the hope that clearer responsibilities will lead to better (and more efficient) governance. In particular, under the reform the:

- State retains the responsibility for setting national norms, ensuring national security, justice, education, employment, public health, taxation, national infrastructure and territorial equilibrium.

- Regions should ensure the coherence and strategy at the level of the department for:

- youth employment and training programmes,

- universities,

- lifelong learning,

- industrial policy,

- regional and sub-regional transportation infrastructure,

- certain healthcare programmes, notably regional hospital agencies, ARH.

- Departments are given substantial additional powers, principally having to do with social policy and local infrastructure projects. In particular, they will be:

- made responsible for the management of the RMI,

- given responsibility for the maintenance of regional infrastructure, including schools and national roadways (but not autoroutes),

- take responsibility for some 100000 school maintenance employees.

- Municipalities remain in charge of the provision of local services.

In order to ensure that sub-national governments have the appropriate incentives to manage their new responsibilities the state will transfer an equivalent amount in financial resources. In particular, it proposes to transfer to the regions part of petrol taxes (Taxe intérieure sur les produits pétroliers, TIPP) and to allow them to set (within bounds) the rate at which the tax will be applied. ${ }^{2}$

Moreover, it intends to improve and simplify the system of regional equalisation so as to ensure that less wealthy subnational governments have the financial means to deliver the services required of them.

1. The bulk of this box is based on the Speech by M. Jean-Pierre Raffarin, the Prime Minister of France, given in Rouen on 28 February 2003 (http://www.premier-ministre.gouv.fr).

2. Such a step requires the approbation of Brussels, which has yet to be provided. 
63. The success of efforts to increase the incentives for municipal level governments to cooperate in the provision of services illustrates the effectiveness of such strategies to increase efficiency and the quality of services. Here, the 1999 reform creating a special category of Public Enterprise for municipal cooperation (Établissements publics de coopération intercommunale, EPCI) has helped overcome the serious problem posed by the large number of municipalities with fewer than 20-30 thousand inhabitants, a level estimated to equal the minimum efficient size for this level of government. These EPCIs permit smaller municipalities to jointly provide services and infrastructures (such as those for local transport and waste management) in conjunction with a larger one, which acts as a hub. ${ }^{24}$ Already some 2360 EPCIs have been formed, covering 90 per cent of France's population, effectively taking over the activities of various other cooperative forms previously created to address this issue. A less clear success are the local public-service companies (Sociétés d'économie mixte locales, SEM), which have until recently enjoyed an unfair competitive advantage vis-à-vis private firms. A recent ruling requiring municipalities to place the management of large projects to public tender should help harness competitive pressures, reduce costs and spur the development of a sounder market for public works at the local level.

64. The benefits of output-based budgeting should be extended to sub-national governments. Technically, there are no obvious impediments to moving in this direction. Within the context of the LOLF, the decentralised services of the State are already moving in this direction (departmental prefectures were some of the first groups to experiment with defining objectives and indicators) but more could be done. A more systematic and rigorous implementation of results-oriented budgeting could, for instance, break down local-level resistance to the closure of under-utilised and uneconomic services, if in fact they resulted in improved services or significant cost savings for the locality.

\section{Summing up}

65. Since the early 1990s, when France's general government deficit reached a disturbing 6 per cent of GDP, the country's public finances have progressed substantially, even though significantly further improvements are required. This principally reflects a substantial increase in taxes and a stabilisation of expenditures' share in output. Looking forward, the ageing of the population is expected to generate substantial new spending pressures and at the same time slow the pace of growth, putting into question the economy's longer-term fiscal sustainability. Given the already very high tax burden, policy needs to focus on controlling the rate of increase in public expenditures, including those of the State and subnational-level governments -- but especially those of the social security system where cost pressures are likely to be strongest. The future progression of ageing-related costs is relatively well known, as is the unsustainability of public finances in the absence of reform (see OECD, 2003, Chapter I). To meet this challenge, fiscal room needs to be made now and the overall debt reduced so that when these additional expenditures arise they can be met without threatening the overall sustainability of public finances.

66. This paper has examined the tools available to policy-makers to meet this challenge and Box 7 summarises its principal recommendations. The clearest message is that given the relatively small size of the State Budget in total spending, the challenge cannot be met by the State sector alone. Social security, as the principal source of spending pressure, must play a role, but so too must sub-national government -- especially if current plans to transfer additional responsibilities to the local level go through. If policymakers are to succeed in directing public expenditure so as to create this room, they will have to clarify governance structures so that those who administer programmes face appropriate incentives to control costs and maximise programme efficiency. Too often financial responsibility and administrative responsibility are not held by the same body so that resulting conflicts contribute to policy inertia and blocked reforms. The authorities' decentralisation programme is a clear and important step towards

24. The responsibilities of the EPCI are defined by the municipalities whose elected members form their managing assemblies. 
clarifying roles. However, it does not address the second major difficulty, the lack of mechanisms to moderate the growth of public spending so as to create the fiscal room necessary to cushion forthcoming spending pressures.

\section{Box 7. Summary of recommendations}

\section{Aggregate fiscal discipline}

- In order to improve the information available to policymakers and to prevent expenditures from rising permanently, measures should systematically include, at all levels of government, evaluations of their medium-term impacts on the general government.

- In order to increase the authorities capacity to reallocate resources, the State and Social Security Budgets should be more clearly integrated into a medium term framework.

- It is important that the macroeconomic framework underlying budgetary assumptions be more closely in line with economic potential.

- Concerning specific programmes, information about individual Budget missions and social security programmes should be precisely displayed as a way to better isolate the influence of different spending programmes.

\section{Ensuring the effectiveness of the new State budget framework law}

- Letting spending Ministries and departments participate actively in the preparation of missions objective and evaluation strategies will be key to ensuring that those who are called upon to implement such objectives see them as fully legitimate.

- In order for new public-expenditure management techniques to improve the quality and cost-effectiveness of programmes, the policy evaluation process needs to be reinforced.

- The resources allocated to evaluation might need to be increased, something that can be achieved through reallocation of posts.

- As a means to combating spending inertia, the authorities could consider making greater use of sunset clauses that require specific task-spending programmes to be abandoned after a set period of time.

- Although the new budgetary framework only applies to the State Budget, the authorities should envisage measures requiring a more regular reporting of the impacts of social security programmes and incorporating a discussion of these into the parliamentary debate on the PLFSS held each year. The benefits of output based budgeting should also be extended to sub-national governments.

\section{Local governments}

- Bringing forward the preparation of local government budgets would help improve co-ordination and the preparation of the general government budget.

- The ongoing reform to rationalise the roles of different sub governmental actors should be phased in as planned. If its spirit is preserved during its realisation, it would go a long way towards generating important efficiency gains.

\section{Mandatory expenditures}

- Transforming into direct transfers the aid the State currently provides the social security system in the form of earmarked taxes would go a long way towards reducing presently observed rigidities in budgetary allocations.

- Making the budgets of the social security regimes more binding would help bring healthcare expenditure under control.

- In order to make individuals and their private insurance schemes more interested in controlling costs, access to basic coverage should be made more universal, consistent with current government's plans, while also conferring more of the overall costs to complementary regimes.

- Specific recommendations concerning the reform of the pension system are outlined at the end of OECD, 2003, Chapter II. 
67. To meet this challenge -- both as concerns sub-national and social service expenditures -- the authorities should consider expanding both the scope and the duration of the budget process to include the social security and sub-national sectors. A more integrated and multiyear budget would help expose all spending to the same degree of oversight and competition, while confronting decision-makers with the medium-term consequences of their actions. To be effective, such a reform would require that Parliament increase its influence over the revenues of the social security funds and introduce mechanisms that make their budgets more binding. Furthermore, the additional autonomy and expanded spending responsibilities that decentralisation will bring to sub-national governments need to be combined with a responsibility to respect national spending norms. Finally, if the medium-term features of such a programme are to help guide policymakers, projections need to be based on prudent macroeconomic assumptions and the sources of future savings need to be identified.

68. Of course, such institutional changes cannot in and of themselves generate the savings necessary to ensure fiscal sustainability. Here, the ongoing reform of the pension and healthcare systems will play critical roles. As the simulations in OECD, 2003, Chapter I make clear, failure to generate the kinds of savings proposed by the authorities between now and 2020 will place serious strain on the economy. Moreover, notwithstanding the ambition of current proposals, this is just a beginning and much more needs to be done to restore equilibrium to the pension regimes.

69. Health reform will also be important. Several propositions currently on the table, including decentralisation, an extended role for complementary coverage, and perhaps a reduction in the range of services covered, would serve to reduce health insurance costs and contribute to their slower progression. However, they do little to make the budget constraint of the system more binding and in this regard the 1999 Economic Survey made a number of suggestions, which remain relevant. For the State Budget, the new budgetary framework may help contribute to a slower and more effective expenditure growth. To maximise the chances that this reform will be successful, the high level of support that it has enjoyed so far will need to be maintained, both at the political level and on the part of all of those responsible for public spending.

70. The fiscal challenges facing France in the coming years are enormous and will require important fiscal adjustments. While the path ultimately chosen will doubtless be different from the one outlined here, it will necessarily address the same problems. Whatever form they take, reforms along these lines could go a long way to helping ensure that France is able to meet its future challenges with a minimum of disruption and while maintaining a high level of public services. 


\section{GLOSSARY OF ACRONYMS}

$\begin{array}{ll}\text { ACOSS } & \text { Central fund for social security } \\ \text { APA } & \text { Personalised assistance allowances to the elderly } \\ \text { APE } & \text { State ownership agency } \\ \text { BAPSA } & \text { Separate annex budget for the agriculture social fund } \\ \text { CADES } & \text { Fund for the amortisation of the social debt } \\ \text { CNAF } & \text { Family social security regime } \\ \text { CNAMTS } & \text { Healthcare social security regime } \\ \text { CNAVTS } & \text { Old age social security regime } \\ \text { COG } & \text { Management target and management conventions between the State and the social } \\ & \text { security regimes } \\ \text { COR } & \text { Retirement Advisory Council } \\ \text { CSG } & \text { Generalised social contribution } \\ \text { EDF } & \text { French Electricity Company } \\ \text { EPICs } & \text { French Public Companies } \\ \text { EPCIs } & \text { Public Companies for municipal cooperation } \\ \text { EU } & \text { European Union } \\ \text { FCATA } & \text { Asbestos workers early retirement fund } \\ \text { FCAATA } & \text { Agriculture work accident fund } \\ \text { FIP } & \text { Local investment funds } \\ \text { FOREC } & \text { Fund for the financing of the reform of the enterprises'social charges } \\ \text { FRR } & \text { Retirement reserve fund } \\ \text { FSV } & \text { Old age solidarity fund } \\ \text { GDP } & \text { Gross Domestic Product } \\ \text { GDF } & \text { French Gas Company } \\ \text { IGF } & \text { General Finance inspectorate } \\ \text { INSEE } & \text { National Institute for Statistics and economic studies } \\ \text { LOLF } & \text { New framework law for the State Budget } \\ \text { MINEFI } & \text { Ministry of Industry, economy and finance } \\ \text { ONDAM } & \text { National health spending target } \\ \text { PLF } & \text { State draft budget } \\ \text { PLFSS } & \text { Draft social security budget } \\ \text { PPES } & \text { Voluntary saving partnership plan } \\ \text { RFF } & \text { French railways infrastructure company } \\ \text { SNCF } & \text { French railways Service Company } \\ \text { UNEDIC } & \text { Organisation in charge of the management of the unemployment insurance scheme } \\ \text { URSAFFs } & \text { Regional agencies in charge for collecting social security contributions } \\ & \end{array}$




\section{BIBLIOGRAPHY}

CHARPIN, J.M. (1999),

L'Avenir de nos Retraites, Rapport du Commissaire au Plan au Premier Ministre, La Documentation Française, Paris.

CHEVAUCHEZ, B. (2002),

"Government budgeting and accounting reforms in France", in Models of Public Budgeting and accounting Reform, OECD.

COMMISSARIAT GENERAL DU PLAN (2002),

Effet de serre: modélisation économique et décision publique, March.

COMMISSARIAT GENERAL DU PLAN (2002),

Avenirs des métiers, November.

CONSEIL D'ORIENTATION DES RETRAITES (2001),

"Retraites : renouveler le contrat social entre les générations - Orientations et débats", Premier rapport, La Documentation Française, Paris.

CONSEIL D'ORIENTATION DES RETRAITES (2001b),

Âge et Travail, La Documentation Française, Paris.

COUR DES COMPTES (2002),

La sécurité sociale.

CREPON, B., R. Desptatz (2001),

"Une nouvelle évaluation des effets des allégements de charges sociales sur les bas salaires", ÉCONOMIE ET STATISTIQUE, No: 348.

DOCTEUR, E. and H. OXLEY (2003),

Health care systems: Lessons from the reform experience.

ECONOMIC POLCIY COMMITTEE OF THE EUROPEAN COMMISSION (2000) Budgetary

challenges posed by ageing populations: the impact on public spending on pensions, health and long-term care for the elderly and the possible indicators of the long-term sustainability of public finances, Commission $\mathrm{f}$ the European Union, Brussels.

IMF (2002),

Article IV Consultation.

INSEE (2002),

"L'évolution de l'emploi faiblement rémunéré au cours des dix dernières années" in L'Economie francaise: Édition 2002-2003", INSEE, Paris. 
MARINI, P. (2002),

"Rapport général au nom de la commission des Finances, du contrôle budgétaire et des comptes économiques de la Nation sur le projet de loi de finances pour 2003 adopté par l'Assemblée nationale", Volume No. 1, November, Paris.

MARLIER, E., M. Cohen-Solal (2002),

"Social Benefits and their redistributive effect in the EU", EUROSTAT Statistics in Focus, Theme 39, EUROSTAT.

$\operatorname{OECD}(2001)$,

Economic Surveys: France.

OECD (2003),

Economic Surveys: France. 


\section{WORKING PAPERS}

The full series of Economics Department Working Papers can be consulted at www.oecd.org/eco/Working_Papers/

408. Russian Industrial Restructuring: Trends in Productivity, Competitiveness and Comparative Advantage (October 2004) Rudiger Ahrend

407. Improving the Capacity to Innovate in Germany (October 2004) Andrés Fuentes, Eckhard Wurzel and Margaret Morgan

406. Tax Treatment of Private Pension Savings in OECD Countries and the Net Tax Cost per Unit of Contribution to Tax-Favoured Schemes

(October 2004) Kwang-Yeol Yoo and Alain de Serres

405. The Reform of the Health Care System in Portugal (October 2004) Stéphanie Guichard

404. Accounting for Russia's Post-Crisis Growth (October 2004) Rudiger Ahrend

403. Restructuring Russia's Electricity Sector: Towards Effective Competition or Faux Liberalisation? (October 2004) William Tompson

402. Russia's Gas Sector: The Endless Wait for Reform? (September 2004) Rudiger Ahrend and William Tompson

401. One Money, One Cycle? Making Monetary Union a Smoother Ride (September 2004) Peter Hoeller, Claude Giorno and Christine de la Maisonneuve

400. Modelling Cyclical Divergence in the Euro Area: The Housing Channel (September 2004) Paul van den Noord

399. Product Market Competition and Economic Performance in Korea (August 2004) Yongchun Baek, Randall Jones and Michael Wise

398. Product Market Competition and Economic Performance in the United States (July 2004) Hannes Suppanz, Michael Wise and Michael Kiley

397. Saving Behaviour and the Effectiveness of Fiscal Policy (July 2004) Luiz de Mello, Per Mathis Kongsrud and Robert Price

396. The impact of exchange rate regimes on real exchange rates in South America, 1990-2002 (June 2004) Anne-Laure Baldi and Nanno Mulder

395. How Market Imperfections and Trade Barriers Shape Specialisation: South America vs. OECD (June 2004) Joaquim Oliveira Martins and Tristan Price

394. Housing Markets, Wealth and the Business Cycle (June 2004) Pietro Catte, Nathalie Girouard, Robert Price and Christophe André

393. Long-Term Budgetary Implications of Tax-Favoured Retirement Saving Plans (June 2004) Pablo Antolin, Alain de Serres and Christine de la Maisonneuve

392. Enhancing Income Convergence in Central Europe after EU Accession (June 2004) Patrick Lenain and Lukasz Rawdanowicz 
391. Asset Price Cycles, “One-Off” Factors and Structural Budget Balances (June 2004) Nathalie Girouard and Robert Price

390. Channels for Narrowing the US Current Account Deficit and Implications for Other Economies (May 2004) Anne-Marie Brook, Franck Sédillot and Patrice Ollivaud

389. Product Market Competition and Economic Performance in Norway (May 2004) Jens Høj and Michael Wise.

388. Product Market Competition and Economic Performance in Sweden (May 2004) Deborah Roseveare, Martin Jørgensen and Lennart Goranson

387. Product Market Competition and Economic Performance in Japan (May 2004) Jens Høj and Michael Wise

386. Migration and Integration of Immigrants in Denmark (May 2004) Deborah Roseveare and Martin Jørgensen

385. Factors Driving Risk Premia

(April 2004) Torsten Sløk and Mike Kennedy

384. Rationalising Public Expenditure in the Slovak Republic (March 2004) Rauf Gönenç and Peter Walkenhorst

383. Product Market Competition and Economic Performance in Switzerland (March 2004) Claude Giorno, Miguel Jimenez and Philippe Gugler

383. Concurrence sur les Marchés de Produits et Performance Économique en Suisse (Mars 2004) Claude Giorno, Miguel Jimenez and Philippe Gugler

382. Differences in Resilience between the Euro-Area and US Economies (March 2004) Aaron Drew, Mike Kennedy and Torsten Sløk

381. Product Market Competition and Economic Performance in Hungary (March 2004) Carl Gjersem, Philip Hemmings and Andreas Reindl

380. Enhancing the Effectiveness of Public Spending: Experience in OECD Countries (February 2004) Isabelle Joumard, Per Mathis Kongsrud, Young-Sook Nam and Robert Price

379. Is there a Change in the Trade-Off between Output and Inflation at Low or Stable Inflation Rates? Some Evidence in the Case of Japan (February 2004) Annabelle Mourougane and Hideyuki Ibaragi

378. Policies bearing on product market competition and growth in Europe (January 2004) Carl Gjersem

377. Reforming the Public Expenditure System in Korea (December 2003) Young-Sook Nam and Randall Jones

376. Female Labour Force Participation: Past Trends and Main Determinants in OECD Countries (December 2003) Florence Jaumotte

375. Fiscal Relations Across Government Levels (December 2003) Isabelle Joumard and Per Mathis Kongsrud 